\title{
A decade of monitoring at Swiss Long-Term Forest Ecosystem Research (LWF) sites: can we observe trends in atmospheric acid deposition and in soil solution acidity?
}

\author{
Elisabeth Graf Pannatier • Anne Thimonier • \\ Maria Schmitt • Lorenz Walthert • Peter Waldner
}

Received: 9 March 2010 / Accepted: 29 September 2010 / Published online: 11 November 2010

(C) Springer Science+Business Media B.V. 2010

\begin{abstract}
Trends in atmospheric acid deposition and in soil solution acidity from 1995 or later until 2007 were investigated at several forest sites throughout Switzerland to assess the effects of air pollution abatements on deposition and the response of the soil solution chemistry. Deposition of the major elements was estimated from throughfall and bulk deposition measurements at nine sites of the Swiss Long-Term Forest Ecosystem Research network (LWF) since 1995 or later. Soil solution was measured at seven plots at four soil depths since 1998 or later. Trends in the molar ratio of base cations to aluminum $(\mathrm{BC} / \mathrm{Al})$ in soil solutions and in concentrations and fluxes of inorganic $\mathrm{N}\left(\mathrm{NO}_{3}-\mathrm{N}+\mathrm{NH}_{4}-\mathrm{N}\right)$, sulfate $\left(\mathrm{SO}_{4}-\mathrm{S}\right)$, and base cations (BC) were used to detect changes in soil solution chemistry. Acid deposition significantly decreased at three out of the nine study sites due to a decrease in total $\mathrm{N}$ deposition. Total $\mathrm{SO}_{4}-\mathrm{S}$ deposition decreased at the nine sites, but due to the relatively low amount of $\mathrm{SO}_{4}-\mathrm{S}$ load compared to $\mathrm{N}$ deposition, it did not contribute to decrease acid deposition significantly. No trend in total $\mathrm{BC}$ deposition was detected. In the soil
\end{abstract}

E. Graf Pannatier $(\varangle) \cdot$ A. Thimonier · M. Schmitt .

L. Walthert · P. Waldner

Swiss Federal Institute for Forest, Snow

and Landscape Research WSL, Zürcherstrasse 111,

8903 Birmensdorf, Switzerland

e-mail: elisabeth.pannatier@wsl.ch solution, no trend in concentrations and fluxes of $\mathrm{BC}, \mathrm{SO}_{4}-\mathrm{S}$, and inorganic $\mathrm{N}$ were found at most soil depths at five out of the seven sites. This suggests that the soil solution reacted very little to the changes in atmospheric deposition. A stronger reduction in base cations compared to aluminum was detected at two sites, which might indicate that acidification of the soil solution was proceeding faster at these sites.

Keywords Acid deposition - Acidification • Soil solution $\cdot$ ICP-Forests

\section{Introduction}

Acid atmospheric deposition has been shown to affect the chemistry of soils and drainage waters in forest ecosystems and accelerate the acidification of soils (e.g., Binkley et al. 1989). Acidifying emissions, especially of sulfur dioxide $\left(\mathrm{SO}_{2}\right)$, have decreased considerably since the mid 1980s across large regions of Europe and North America as a result of air pollution abatements. After a strong reduction between 1985 and the mid 1990s, S emissions declined more slowly (Schöpp et al. 2003). Emissions of oxidized and reduced nitrogen in Europe have been reduced during the last 15-20 years, but they have remained on a high level. The reduction of acid deposition has raised questions about the recovery of surface waters 
and soils from acidification. The data analysis of the ICP-Water Program between 1985 and 1995 showed an increase in alkalinity, which was regarded as a recovery from acidification, in streams and lakes in response to the reduction in sulfate deposition (Stoddard et al. 1999; Evans et al. 2001). Other studies have reported a delay or even no reaction in respect to water acidification, which was attributed to the release of previously stored sulfate from developed soils, coupled to the leaching of aluminum ( $\mathrm{Al})$ and base cations (BC; e.g. Alewell et al. 2000a; Prechtel et al. 2001; Armbruster et al. 2003). Chronic high atmospheric input of nitrogen $(\mathrm{N})$ also leads to a net acidification in $\mathrm{N}$-rich forest ecosystem, where inorganic $\mathrm{N}$ (mostly $\mathrm{NO}_{3}^{-}$), exceeding the plant and microbe demand, is leached below the root zone (Gundersen et al. 2006). The release of the strong acid anions $\mathrm{SO}_{4}^{2-}$ and $\mathrm{NO}_{3}^{-}$in the soil solution, balanced by cation leaching, may significantly contribute to the acidification of soils and surface waters (Reuss and Johnson 1986). Several field studies have shown that soil solution acidification was still progressing in the late 1990s, despite reduced deposition (Blaser et al. 1999; Alewell et al. 2000b; Moffat et al. 2002). An increasing net loss of BC from ecosystems due to a combination of high anion leaching and reduction in BC deposition has been reported in several catchments in Europe (Alewell et al. 2001) and North America (Likens et al. 1998; Watmough and Dillon 2004). Depletion of exchangeable base cations in soils has been suggested as a major process preventing the recovery of surface waters despite large reductions in $\mathrm{S}$ emissions.

Trend analyses in soil solution collected in forest ecosystems were performed in several countries in Europe in the late 1980s and in the 1990s such as in Belgium (Neirynck et al. 2002), Germany (e.g. Meesenburg et al. 1995; Alewell et al. 2000b; Armbruster et al. 2003), Norway (Kvaalen et al. 2002; Moffat et al. 2002), Sweden (Fölster et al. 2003), and Switzerland (Blaser et al. 1999). Later, the studies of Boxman et al. (2008), Oulehle et al. (2006), and Neirynck et al. (2008) reported longterm trends of the soil solution chemistry until 2005-2007 at single forest plots. Very few studies (e.g. Vanguelova et al. 2010) investigated the response of the soil solution quality to declining acid deposition after 2000 in different forest ecosystems at a larger spatial scale. However, these data are relevant, not only to show the effects of the measures taken for air quality improvement and to survey the potential ecological risks for forest and aquatic ecosystems at the national or regional level but also to calibrate and validate dynamic soil chemistry models (Reinds et al. 2009a). The models are getting more complex and integrate not only the effects of deposition on soils but also the response to climate change and forest management practices (e.g., ForSafe in Wallman et al. 2005; Belyazid et al. 2006; Reinds et al. 2009b).

The monitoring of Swiss Level II plots in the framework of the International Co-operative Programme on Assessment and Monitoring of Air Pollution Effects on Forests (ICP-Forests; e.g. UNECE 2008) provides useful data to assess the response of soil solution to decreasing acid deposition in Switzerland. The Swiss Long-Term Forest Ecosystem Research LWF was established in 1994, with the aim of gaining a better knowledge of how natural and anthropogenic stresses affect forests in the long term (Cherubini and Innes 2000; Thimonier et al. 2001). Deposition measurements started in 1995 or later at nine sites and soil solution sampling began between 1998 and 2000 at seven sites. To assess the effects of air pollution abatements on acid deposition and the response of the soil solution chemistry, trends in acid deposition and in soil solution acidity until 2007 were investigated in various mature forest stands in different climatic regions of Switzerland. The measurement period corresponds to the phase of slow decline in $\mathrm{S}$ emissions and of rather constant $\mathrm{N}$ and $\mathrm{BC}$ emissions in Switzerland (FOEN 2009). The long-term trends in the ratios of $\mathrm{BC}$ to $\mathrm{Al}$ in the soil solution (with $\mathrm{BC}$ corresponding to the sum of the molar concentrations of $\mathrm{Ca}^{2+}, \mathrm{Mg}^{2+}$, and $\mathrm{K}^{+}$, and $\mathrm{Al}$ representing the total molar concentration of dissolved aluminum) were used to characterize soil solution acidification (Blaser et al. 1999; Neirynck et al. 2002; Graf Pannatier et al. 2005). Depletion of exchangeable base cations by acidification might lead to a decrease in base saturation and possibly in a decrease in the $\mathrm{BC} / \mathrm{Al}$ ratio in the soil solution (Cronan and Grigal 1995). Input and output budget of inorganic $\mathrm{N}\left(\mathrm{NO}_{3}-\mathrm{N}+\mathrm{NH}_{4}-\mathrm{N}\right)$ and 
sulfate $\left(\mathrm{SO}_{4}^{2-}\right)$ were also analyzed to assess the response of soil solution chemistry to changing deposition (Alewell et al. 2001; Vanguelova et al. 2010). Although precipitation amount and water fluxes have been shown to influence total deposition (e.g. Thimonier et al. 2005) and element fluxes in the soil solution (e.g. Michalzik et al. 2001), very few studies have considered this aspect in their trend analysis.

The three main objectives of this study were (1) to assess the effects of emission abatement on acid deposition at nine forest sites throughout Switzerland, (2) to investigate the response of the soil solution chemistry to acid deposition at seven sites, (3) to check the influence of the variations in precipitation amount and soil water fluxes on the trends of acid deposition and soil solution chemistry. The observation period considered in this study started in 1995 or later until 2007.

\section{Material and methods}

Sites

The nine study sites are part of a national forest monitoring network that was set up within the framework of the Swiss Long-Term Forest
Ecosystem Research project LWF. These sites are part of the Level II plots network of ICP-Forests.

The sites are distributed across Switzerland from the Jura Mountains to the southern part of the Alps (Fig. 1). The main characteristics of the study sites, including location, main tree species, and soil type, are given in Tables 1 and 2 . Seven main tree species are represented including beech (Fagus sylvatica) and Norway spruce (Picea abies). The forests were not managed during the whole observation period. The sites cover a broad range of soils, from calcareous soils to podzols. The type of parent material (carbonate or free of carbonate) and the depth of the first appearance of carbonate in the fine earth are presented in Table 2. The chemistry ( $\mathrm{pH}$, effective cation exchange capacity, and base saturation) of the soil profiles is provided in Walthert et al. (2003) and summarized in Table 2.

\section{Atmospheric deposition}

Atmospheric deposition was monitored at nine sites for a period of 8 to 13 years (starting in 1995 at the earliest and in 2000 at the latest until 2007) using the throughfall method (Table 1). This method relies on the parallel sampling of throughfall and precipitation in an open area close
Fig. 1 Location of study sites with sampling of atmospheric deposition and soil solution

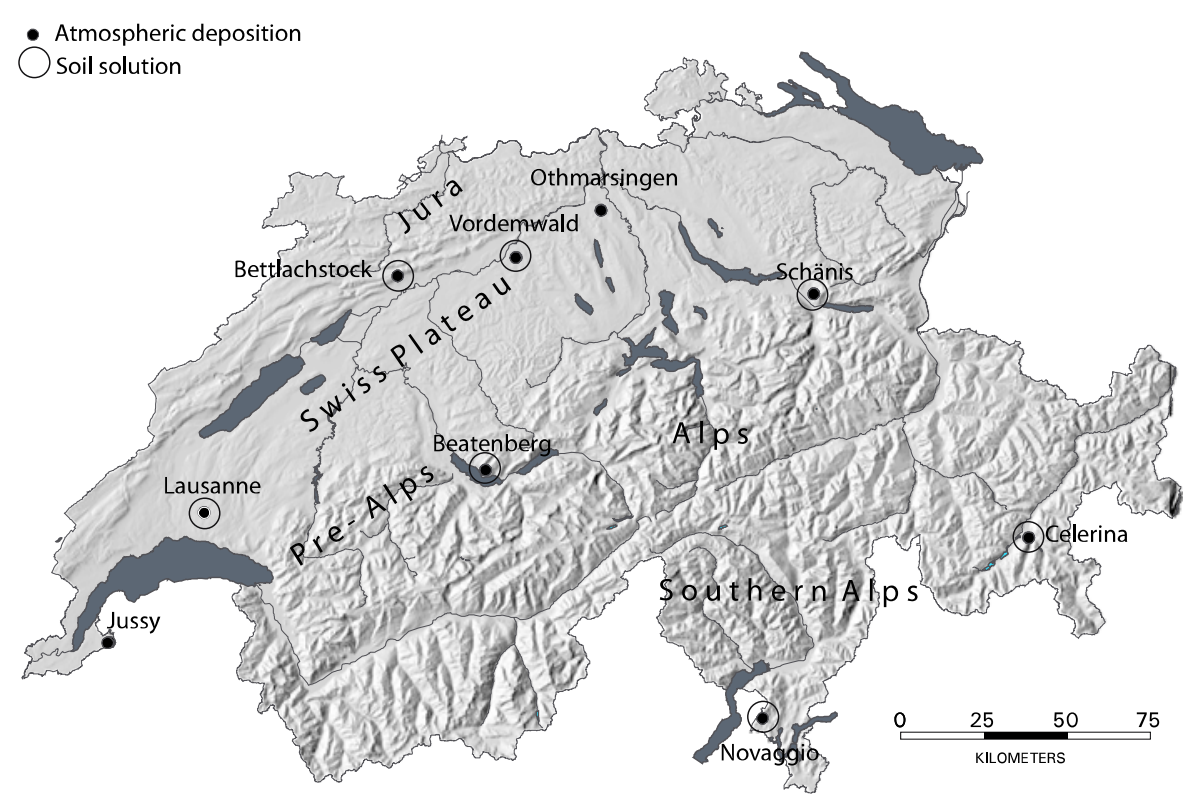




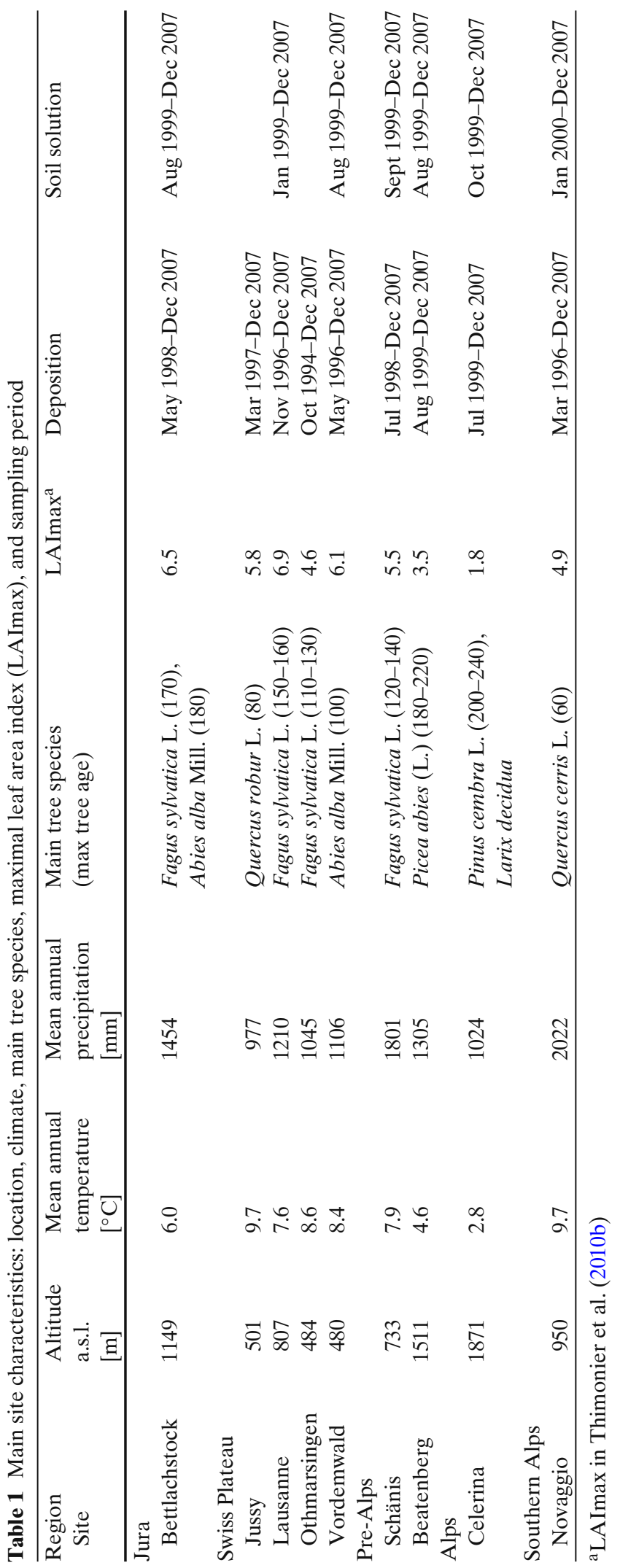




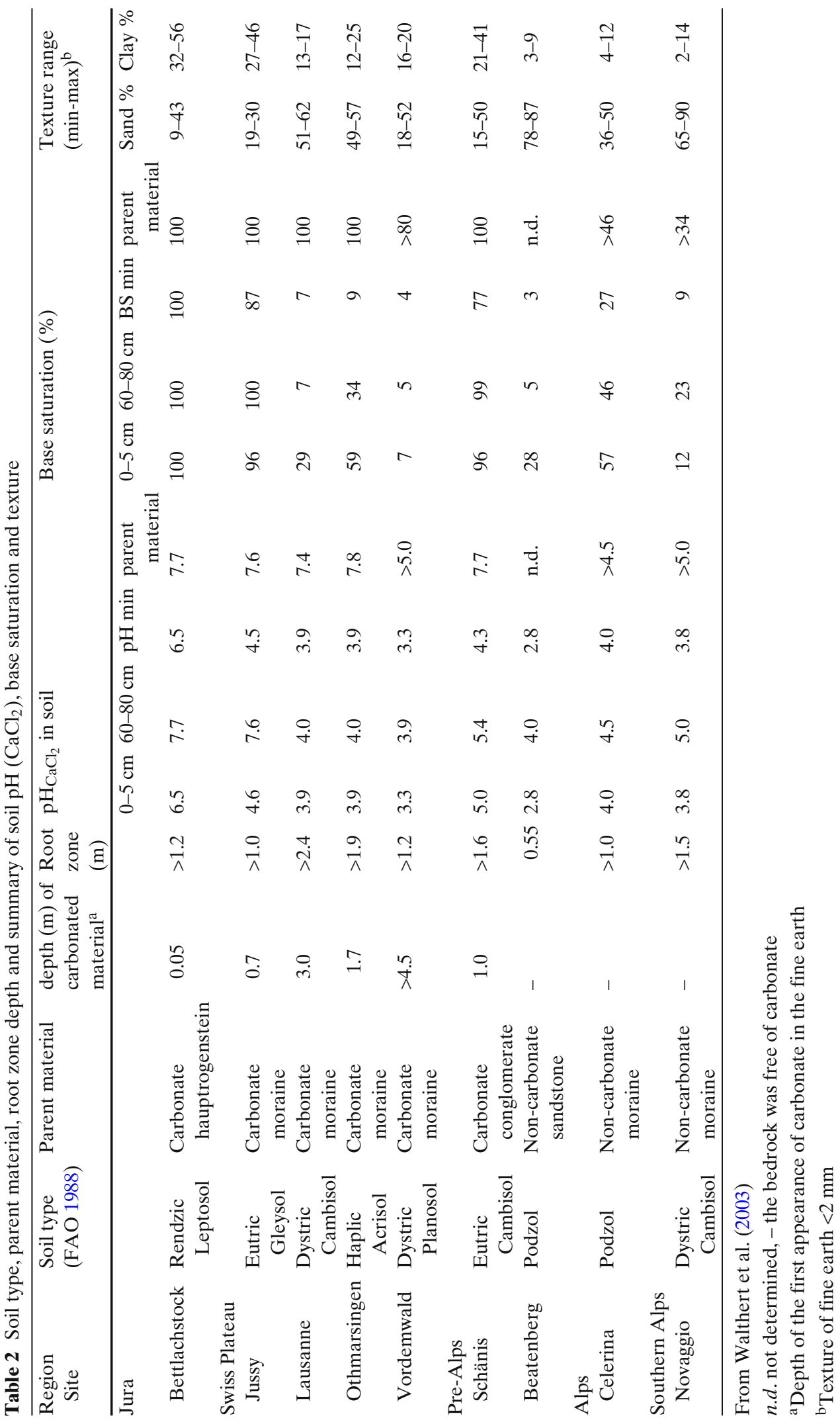


to the forest stand. Precipitation in the open area was collected with three funnel-type $\left(100 \mathrm{~cm}^{2}\right.$ opening) polyethylene collectors (bulk precipitation). At the sites where abundant snowfall could be expected (Bettlachstock, Beatenberg, Schänis, Celerina, Lausanne, and Novaggio), the funneltype collectors were replaced by a single buckettype snow collector (30 cm diameter) in winter. Throughfall was sampled with 16 funnel-type collectors systematically distributed into two sets of equal numbers in two $43 \times 43 \mathrm{~m}$ subplots inside the forest plot. The collectors were replaced by four $30-\mathrm{cm}$ diameter buckets for snow collection during the winter at the sites where abundant snowfall was expected (see above). A detailed description of the sampling design is provided in Thimonier et al. (2005).

Both throughfall and bulk deposition samples were collected every two weeks except during the winter in Celerina and in Bettlachstock (every 4 weeks). Upon arrival of the samples in the laboratory, the sampled were pooled and filtered $(0.45 \mu \mathrm{m})$. Ammonium $\left(\mathrm{NH}_{4}^{+}\right)$was determined colorimetrically through automated flow injection analysis. Total dissolved $\mathrm{Al}$, calcium $\left(\mathrm{Ca}^{2+}\right)$, magnesium $\left(\mathrm{Mg}^{2+}\right)$, potassium $\left(\mathrm{K}^{+}\right)$, and sodium $\left(\mathrm{Na}^{+}\right)$were determined by inductively coupled plasma-atomic emission spectrometry. Nitrate $\left(\mathrm{NO}_{3}^{-}\right)$, sulfate $\left(\mathrm{SO}_{4}^{2-}\right)$ and chloride $\left(\mathrm{Cl}^{-}\right)$ were measured by ion chromatography (DX-120, Dionex). The $\mathrm{pH}$ of the samples was also measured, but because of the use of different $\mathrm{pH}$ electrodes during the observation period and the lack of accuracy in the weak acid range $(\mathrm{pH} 5-6)$ revealed from international ring tests, the measurements, and especially trend analysis of $\mathrm{pH}$ are not presented in this paper.

Throughfall and bulk deposition fluxes were calculated multiplying precipitation amount and concentrations for each collection interval and were summed over months and calendar years, using time weighting to interpolate at transitions between months.

To estimate the total deposition, we used the canopy budget model developed by Ulrich (1983), synthesized by De Vries et al. (2001). In this model, throughfall fluxes represent total deposition plus or minus canopy exchanges (leaching or uptake). Sodium is assumed to interact little with the canopy and is used as a tracer for estimating the dry deposition of base cations. Other assumptions in the model include the relative exchange capacities of protons, ammonium, and nitrate. In our calculations, the estimated leaching of weak acids was also taken into account. All equations are given in Thimonier et al. (2005).

Based on the Manual on methodologies and criteria for modeling and mapping critical loads and levels of ICP-Mapping (UNECE 2004), the load of acidity (TDA) was defined as the sum of total deposition of strong acid anions minus nonsea-salt cations plus non-sea-salt chloride:

$\mathrm{TDA}=\mathrm{TDS}^{*}+\mathrm{TDN}-\mathrm{TDBC}^{*}+\mathrm{TDCl}^{*}$

where TDS, TDN, TDBC, TDCl are the total atmospheric deposition of sulfur (S), nitrogen $(\mathrm{N})$, base cations $\left(\mathrm{BC}=\mathrm{Ca}^{2+}+\mathrm{Mg}^{2+}+\mathrm{K}^{+}\right)$ and chloride $\left(\mathrm{Cl}^{-}\right)$respectively with all terms in $\mathrm{kmol}_{\mathrm{c}} \mathrm{ha}^{-1} \mathrm{a}^{-1}$. A factor of 2 and $1 \mathrm{eq} \mathrm{mol}^{-1}$ of deposited $\mathrm{S}$ and $\mathrm{N}$ respectively was used in Eq. 1. Total deposition denoted with an asterisk was corrected for sea-salt, using sodium as a tracer for sea-salt (UNECE 2004). Since the aim of the Convention on Long-range Transboundary Air Pollution is to reduce anthropogenic emissions of $\mathrm{S}$ and $\mathrm{N}$, total deposition derived from sea-salt was not considered in the balance (UNECE 2004). Total deposition was calculated on an annual basis. For trend analysis, it was also calculated at the monthly basis but the assumptions of the canopy budget model might not be valid at that time scale.

\section{Soil solution}

Soil solution was analyzed at seven sites for a period of 8-9 years since 1999/2000 until 2007 (Table 1). At each site, it was collected at eight sampling points systematically distributed in one $43 \times 43 \mathrm{~m}$ subplot where eight of the throughfall collectors were also installed. Soil solution was sampled below the litter Oi layer or in the humus Oe horizon (defined as $0 \mathrm{~cm}$ of depth) using zero-tension lysimetry with Plexiglas plates and in the mineral horizons at three depths $(15,50$, and $80 \mathrm{~cm}$ ) using tension lysimetry with ceramic cups (highflow porous ceramic cups, Soil moisture Equipment Cop. Santa Barbara, USA). At the beginning of each sampling period, a vacuum of 
$500 \mathrm{hPa}$ was applied to the suction cups. The detailed sampling method is described in Graf Pannatier et al. (2004). Soil solution was taken every 2 weeks, together with the precipitation samples. Upon arrival of the samples in the laboratory, the samples were pooled, filtered $(0.45 \mu \mathrm{m})$ and analyzed for $\mathrm{pH}$. The same elements as those measured in the precipitation samples were determined in the soil solution samples. Only mean $\mathrm{pH}$ values were presented in this paper. Trend analysis of $\mathrm{pH}$ was not performed for the same reasons as those mentioned for the deposition samples.

The molar $\mathrm{BC} / \mathrm{Al}$ ratio in the soil solution (with $\mathrm{BC}$ corresponding to the sum of $\mathrm{Ca}^{2+}, \mathrm{Mg}^{2+}$, and $\mathrm{K}^{+}$, and $\mathrm{Al}$ representing the total concentration of dissolved $\mathrm{Al}$ ) was calculated for each sample.

In addition to soil solution collection, the soil matric potential $\Psi$ was measured every two weeks at five depths $(15,30,50,80$, and $130 \mathrm{~cm})$ with at least eight tensiometers per depth installed permanently in the soil. The lower limit of the measurable range was $-90 \mathrm{kPa}$. These measurements were used to check the plausibility of results from water balance model (see below).

Modelling of water and element fluxes in soils

CoupModel, a coupled heat and mass transfer model for soil-plant-atmosphere systems (Jansson and Karlberg 2004) was used to simulate daily matric potential and daily water fluxes at the seven sites where soil solution was collected. The meteorological data (air temperature, precipitation, relative humidity, global radiation, and wind speed) came from the weather station installed at the study site. Stand characteristics and soil properties were available in Walthert et al. (2003) and maximal leaf area index $\left(\mathrm{LAI}_{\max }\right)$ in Thimonier et al. (2010b; Table 1). Pedo-transfer functions derived from soil texture, bulk density and organic matter content (Tables 70 and 72 in KA5 2005) were used to estimate the water contents at saturation, field capacity and wilting point. The van Genuchten parameters were fitted to these points by Schramm et al. (2006) and were applied to the soil horizons of the study sites.

Daily element fluxes were calculated by multiplying the concentrations in the soil solution mea- sured during each 2-week sampling period with the modeled daily water fluxes at each depth. Daily fluxes were cumulated to monthly and yearly fluxes.

Trend analysis

The nonparametric seasonal Mann-Kendall Test (MKT) (Hirsch and Slack 1984) was applied to detect monotonic trends in monthly data. Trend slopes were calculated using Sen's slope estimates, which is the median change between years for all seasonal blocks (Sen 1968). Partial seasonal Mann-Kendall Tests (PMKT) were also applied to find out whether the temporal variations of the studied variables could be explained by fluctuations of precipitation amount or soil water fluxes (Libiseller and Grimvall 2002). Simple Mann-Kendall Tests (without seasonality) were applied to annual fluxes. All Mann-Kendall Tests were computed using the MULTMK/PARTMK program (Libiseller 2004).

\section{Results}

Trends in acid atmospheric deposition

Annual precipitation, acid deposition (TDA) and the contributions of total deposition of sulfur (TDS*), nitrogen (TDN), and base cations (TDBC*) to the load of acidity during the observation period (since 1995 or later until 2007) are illustrated in Fig. 2. The range of TDA differed between the regions. When considering the mean annual TDA between 2000 and 2007 at all plots, the lowest values were found in Celerina in the Alps $\left(-0.02 \mathrm{kmol}_{\mathrm{c}} \mathrm{ha}^{-1} \mathrm{a}^{-1}\right)$, the highest in Novaggio in southern Switzerland $\left(1.99 \mathrm{kmol}_{\mathrm{c}} \mathrm{ha}^{-1} \mathrm{a}^{-1}\right)$, and in Schänis in the Pre-Alps $\left(1.70 \mathrm{kmol}_{\mathrm{c}} \mathrm{ha}^{-1} \mathrm{a}^{-1}\right)$. Intermediate values were found on the Swiss Plateau (from 0.35 to $1.24 \mathrm{kmol}_{\mathrm{c}} \mathrm{ha}^{-1} \mathrm{a}^{-1}$ in Othmarsingen, Vordemwald, Lausanne, Jussy), in the Jura (0.91 $\mathrm{kmol}_{\mathrm{c}} \mathrm{ha}^{-1} \mathrm{a}^{-1}$ in Bettlachstock), and in the Pre-Alps (0.56 kmol $\mathrm{ha}^{-1} \mathrm{a}^{-1}$ in Beatenberg).

The main contributor to acid deposition (TDA) during the observation period was nitrogen deposition (TDN). Mann-Kendall Tests on annual TDA indicated significant decreasing trends $(p<0.05)$ at three sites on the Swiss Plateau (Othmarsingen, 

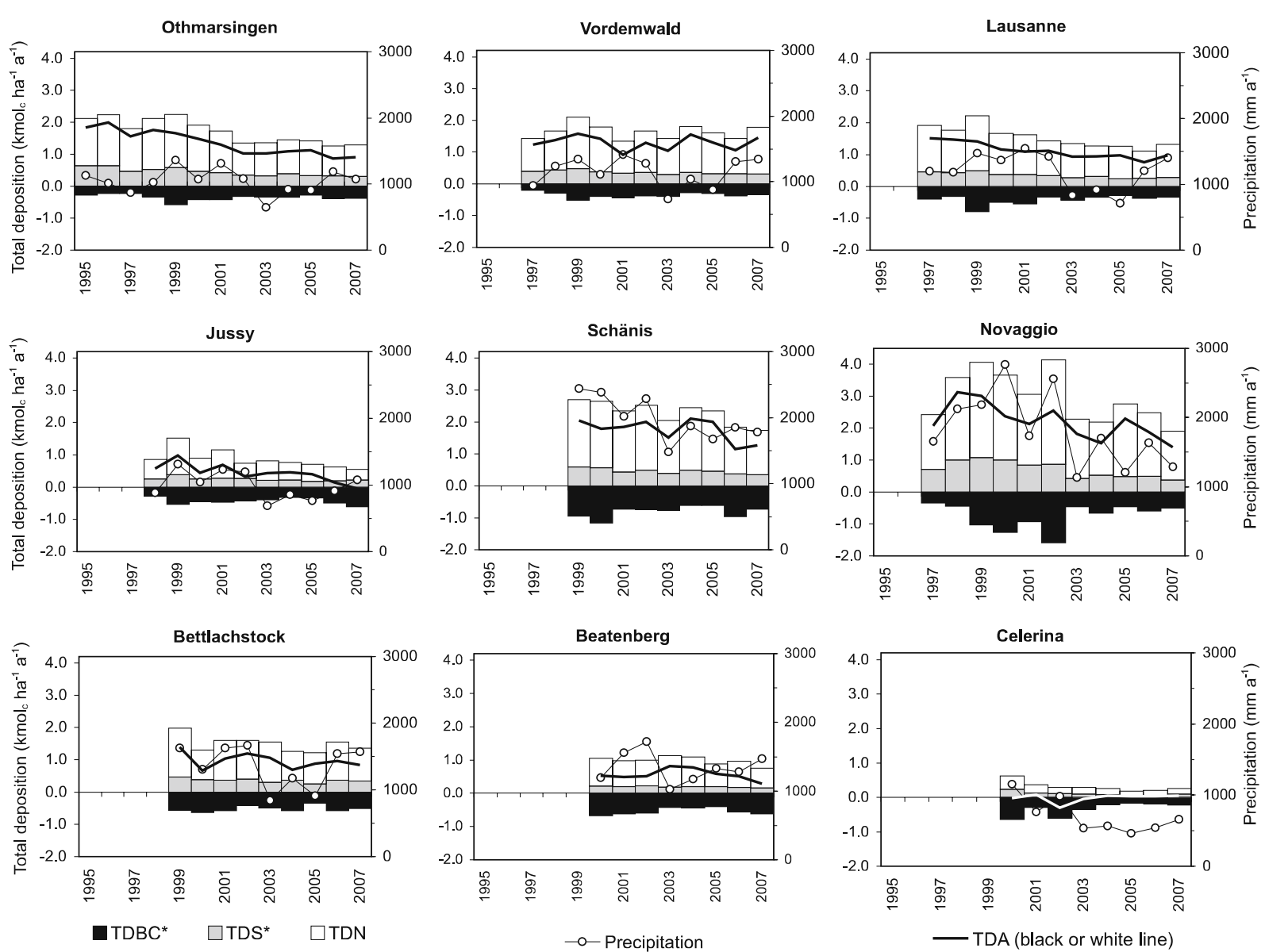

Fig. 2 Annual total acid deposition (TDA), total deposition of sulfur (TDS*), nitrogen (TDN), and base cations (TDBC*) with * denoting correction for sea-salt, and pre-

Lausanne, Jussy) and in Novaggio in southern Switzerland (Table 3). The Sen's slopes were quite similar at the three sites on the Swiss Plateau $\left(-0.07 \mathrm{kmol}_{\mathrm{c}} \mathrm{ha}^{-1} \mathrm{a}^{-1}\right)$ and higher in Novaggio $\left(-0.14 \mathrm{kmol}_{\mathrm{c}} \mathrm{ha}^{-1} \mathrm{a}^{-1}\right)$. The decrease in annual TDA was mainly due to a significant decrease in TDN of ca $0.06 \mathrm{kmol}_{\mathrm{c}} \mathrm{ha}^{-1} \mathrm{a}^{-1}$. In Novaggio, it was mainly caused by the decline in TDS* (Table 3); TDN also tended to decline (Fig. 2) but the decrease was not significant. TDS* decreased significantly at the nine plots, but due to the relatively low amount of TDS* compared to TDN (on average $30 \%$ ), it did not contribute to decrease TDA significantly (except in Novaggio). Variations of TDBC* during the observation period were large, with higher values between 1999 and 2002 at all plots. This explains the significant cipitation in open area $\left(\mathrm{mm} \mathrm{a}^{-1}\right)$ at the 9 sites since 1995 or later until 2007. See Eq. 1 in text for the calculation of TDA

decreasing trend of TDBC* in Celerina (Table 3) where deposition measurements started in 2000 (Fig. 2). TDCl* was close to zero at all plots (95th percentile $=0.032 \mathrm{kmol}_{\mathrm{c}} \mathrm{ha}^{-1} \mathrm{a}^{-1}$ ) and therefore no trend analysis was performed. Partial MannKendall Tests calculated on annual total deposition (Table 3) indicated that variations in precipitation amount were not responsible $(p<0.05)$ for the trends in TDA, TDN, and TDS*, except in Schänis (TDS* and TDN) and in Novaggio (TDA).

Seasonal Mann-Kendall tests were also performed with the monthly values of TDA, TDS*, TDN, and TDBC*. The Sen's slopes calculated with monthly values over the whole observation period were similar or slightly smaller than those computed with annual values (Table 3 ). Similarly to the findings of Staelens et al. (2008), these 
Table 3 Annual trend indicated by Sen's slope for $p<0.05$ in precipitation amount $\left(\mathrm{mm} \mathrm{a}^{-1}\right)$ and in total deposition $\left(\mathrm{kmol}_{\mathrm{c}} \mathrm{ha}^{-1} \mathrm{a}^{-1}\right)$ of acidity (TDA), sulfur (TDS*), and base cations (TDBC $\left.{ }^{*}\right)$ with * denoting correction for sea-salt

\begin{tabular}{|c|c|c|c|c|c|}
\hline & Number & Number & Precipitation & & \\
\hline & of years & of months & Starting value & Annual & Monthly \\
\hline & & & $\left(\mathrm{mm} \mathrm{a}^{-1}\right)$ & $\operatorname{Sen}\left(\mathrm{mm} \mathrm{a}^{-1}\right)$ & $\overline{\operatorname{Sen}\left(\mathrm{mm} \mathrm{a}^{-1}\right)}$ \\
\hline Jura & & & & & \\
\hline Bettlachstock 1999-2007 & 9 & 108 & 1625 & - & - \\
\hline Swiss Plateau & & & & & \\
\hline Jussy 1998-2007 & 10 & 120 & 885 & - & - \\
\hline Lausanne 1997-2007 & 11 & 132 & 1197 & - & - \\
\hline Othmarsingen 1995-2007 & 13 & 156 & 1127 & - & - \\
\hline Vordemwald 1997-2007 & 11 & 132 & 941 & - & - \\
\hline Pre-Alps & & & & & \\
\hline Schänis 1999-2007 & 9 & 108 & 2441 & $*-84$ & - \\
\hline Beatenberg 2000-2007 & 8 & 96 & 1196 & - & - \\
\hline Alps & & & & & \\
\hline Celerina 2000-2007 & 8 & 96 & 1152 & - & $*-28$ \\
\hline Southern Alps & & & & & \\
\hline Novaggio 1997-2007 & 11 & 132 & 1654 & - & - \\
\hline & TDA & & & & \\
\hline & Starting value & Annual & & Monthly & \\
\hline & $\left(\mathrm{kmol}_{\mathrm{c}} \mathrm{ha}^{-1} \mathrm{a}^{-1}\right)$ & $\begin{array}{l}\text { Sen } \\
\left(\mathrm{kmol}_{\mathrm{c}} \mathrm{ha}^{-1} \mathrm{a}^{-1}\right)\end{array}$ & PMKT & $\begin{array}{l}\text { Sen } \\
\left(\mathrm{kmol}_{\mathrm{c}} \mathrm{ha}^{-1} \mathrm{a}^{-1}\right)\end{array}$ & PMKT \\
\hline Jura & & & & & \\
\hline Bettlachstock 1999-2007 & 1.45 & - & - & - & - \\
\hline Swiss Plateau & & & & & \\
\hline Jussy 1998-2007 & 0.61 & $* *-0.070$ & $*$ & $*-0.046$ & $*$ \\
\hline Lausanne 1997-2007 & 1.55 & $* *-0.070$ & $* *$ & $* *-0.070$ & $* *$ \\
\hline Othmarsingen 1995-2007 & 1.86 & $* * *-0.095$ & $* * *$ & $* * *-0.095$ & $* * *$ \\
\hline Vordemwald 1997-2007 & 1.28 & - & - & - & - \\
\hline Pre-Alps & & & & & \\
\hline Schänis 1999-2007 & 2.09 & - & - & - & - \\
\hline Beatenberg 2000-2007 & 0.53 & - & - & - & - \\
\hline Alps & & & & & \\
\hline Celerina 2000-2007 & 0.00 & - & - & - & - \\
\hline Southern Alps & & & & & \\
\hline Novaggio 1997-2007 & 2.07 & $*-0.140$ & - & ** -0.132 & $*$ \\
\hline & TDS* & & & & \\
\hline & Starting value & Annual & & Monthly & \\
\hline & $\left(\mathrm{kmol}_{\mathrm{c}} \mathrm{ha}^{-1} \mathrm{a}^{-1}\right)$ & $\begin{array}{l}\text { Sen } \\
\left(\mathrm{kmol}_{\mathrm{c}} \mathrm{ha}^{-1} \mathrm{a}^{-1}\right)\end{array}$ & PMKT & $\begin{array}{l}\text { Sen } \\
\left(\mathrm{kmol}_{\mathrm{c}} \mathrm{ha}^{-1} \mathrm{a}^{-1}\right)\end{array}$ & PMKT \\
\hline Jura & & & & & \\
\hline Bettlachstock 1999-2007 & 0.44 & $*-0.013$ & $* *$ & $*-0.015$ & $*$ \\
\hline Swiss Plateau & & & & & \\
\hline Jussy 1998-2007 & 0.23 & $*-0.011$ & $*$ & $*-0.014$ & $*$ \\
\hline Lausanne 1997-2007 & 0.44 & $* *-0.022$ & $* * *$ & ** -0.025 & $* *$ \\
\hline Othmarsingen 1995-2007 & 0.62 & $* * *-0.028$ & $* * *$ & ** -0.020 & $* * *$ \\
\hline Vordemwald 1997-2007 & 0.38 & $* *-0.013$ & $* *$ & $*-0.012$ & $* *$ \\
\hline Pre-Alps & & & & & \\
\hline Schänis 1999-2007 & 0.56 & ** -0.028 & - & $*-0.011$ & - \\
\hline Beatenberg 2000-2007 & 0.20 & $*-0.006$ & $*$ & $*-0.008$ & $*$ \\
\hline Alps & & & & & \\
\hline Celerina 2000-2007 & 0.21 & $*-0.013$ & $*$ & ** -0.010 & - \\
\hline Southern Alps & & & & & \\
\hline Novaggio 1997-2007 & 0.71 & $*-0.067$ & $* *$ & ** -0.053 & * \\
\hline
\end{tabular}


Table 3 (continued)

\begin{tabular}{|c|c|c|c|c|c|}
\hline & \multicolumn{5}{|l|}{ TDN } \\
\hline & \multirow{2}{*}{$\begin{array}{l}\text { Starting value } \\
\left(\mathrm{kmol}_{\mathrm{c}} \mathrm{ha}^{-1} \mathrm{a}^{-1}\right)\end{array}$} & \multicolumn{2}{|l|}{ Annual } & \multicolumn{2}{|l|}{ Monthly } \\
\hline & & $\begin{array}{l}\text { Sen } \\
\left(\mathrm{kmol}_{\mathrm{c}} \mathrm{ha}^{-1} \mathrm{a}^{-1}\right)\end{array}$ & $\overline{\mathrm{PMKT}}$ & $\begin{array}{l}\text { Sen } \\
\left(\mathrm{kmol}_{\mathrm{c}} \mathrm{ha}^{-1} \mathrm{a}^{-1}\right)\end{array}$ & PMKT \\
\hline \multicolumn{6}{|l|}{ Jura } \\
\hline Bettlachstock 1999-2007 & 1.50 & - & - & - & - \\
\hline \multicolumn{6}{|l|}{ Swiss Plateau } \\
\hline Jussy 1998-2007 & 0.61 & $* *-0.057$ & $* *$ & $*-0.045$ & $*$ \\
\hline Lausanne 1997-2007 & 1.45 & $* * *-0.061$ & $* * *$ & $* *-0.064$ & $* *$ \\
\hline Othmarsingen 1995-2007 & 1.48 & $* *-0.057$ & $* *$ & $* *-0.057$ & $* *$ \\
\hline Vordemwald 1997-2007 & 1.04 & - & - & - & - \\
\hline \multicolumn{6}{|l|}{ Pre-Alps } \\
\hline Schänis 1999-2007 & 2.10 & $* *-0.076$ & - & $* *-0.057$ & * \\
\hline Beatenberg 2000-2007 & 0.83 & - & - & - & - \\
\hline \multicolumn{6}{|l|}{ Alps } \\
\hline Celerina 2000-2007 & 0.40 & $*-0.020$ & - & $*-0.015$ & - \\
\hline \multicolumn{6}{|l|}{ Southern Alps } \\
\hline \multirow[t]{4}{*}{ Novaggio 1997-2007 } & 1.71 & - & - & - & - \\
\hline & \multicolumn{5}{|l|}{ TDBC $^{*}$} \\
\hline & \multirow{2}{*}{$\begin{array}{l}\text { Starting value } \\
\left(\mathrm{kmol}_{\mathrm{c}} \mathrm{ha}^{-1} \mathrm{a}^{-1}\right)\end{array}$} & \multicolumn{2}{|l|}{ Annual } & \multicolumn{2}{|l|}{ Monthly } \\
\hline & & $\begin{array}{l}\text { Sen } \\
\left(\mathrm{kmol}_{\mathrm{c}} \mathrm{ha}^{-1} \mathrm{a}^{-1}\right)\end{array}$ & PMKT & $\begin{array}{l}\text { Sen } \\
\left(\mathrm{kmol}_{\mathrm{c}} \mathrm{ha}^{-1} \mathrm{a}^{-1}\right)\end{array}$ & PMKT \\
\hline \multicolumn{6}{|l|}{ Jura } \\
\hline Bettlachstock 1999-2007 & 0.48 & - & - & $*-0.024$ & $*$ \\
\hline \multicolumn{6}{|l|}{ Swiss Plateau } \\
\hline Jussy 1998-2007 & 0.23 & - & - & - & - \\
\hline Lausanne 1997-2007 & 0.34 & - & - & - & - \\
\hline Othmarsingen 1995-2007 & 0.24 & - & - & - & - \\
\hline Vordemwald 1997-2007 & 0.14 & - & - & - & - \\
\hline \multicolumn{6}{|l|}{ Pre-Alps } \\
\hline Schänis 1999-2007 & 0.57 & - & - & $*-0.037$ & - \\
\hline Beatenberg 2000-2007 & 0.50 & - & * & - & $*$ \\
\hline \multicolumn{6}{|l|}{ Alps } \\
\hline Celerina 2000-2007 & 0.61 & $* 0.055$ & - & $*-0.021$ & - \\
\hline \multicolumn{6}{|l|}{ Southern Alps } \\
\hline Novaggio 1997-2007 & 0.33 & - & - & - & - \\
\hline
\end{tabular}

The trends were computed with the Mann-Kendall Test with annual and monthly values. Starting value: sum or mean of the first year of measurement

$n$ number of months used in the MKT, PMKT is the partial MKT performed with precipitation as explanatory variable, - not significant $(p<0.05)$

*** $\left.p<0.001,{ }^{* *} p<0.01,{ }^{*} p<0.05\right)$ is given for each variable to the left of the Sen's slope and for each PMKT to the right of the Sen's slope

results suggest that the canopy budget model can be applied on a monthly basis, provided reliable chemical analyses and data quality checking.

Throughfall fluxes of inorganic $\mathrm{N}\left(\mathrm{NO}_{3}-\mathrm{N}+\right.$ $\left.\mathrm{NH}_{4}-\mathrm{N}\right), \mathrm{S}\left(\mathrm{SO}_{4}-\mathrm{S}\right)$, and base cations $(\mathrm{Ca}, \mathrm{Mg}$, $\mathrm{K})$ without any sea-salt correction showed similar trends as those found in total deposition (Table 4). The seasonal Mann-Kendall tests performed on the monthly values indicate that throughfall $\mathrm{S}$ fluxes decreased at all plots at rates ranging between -0.009 and $-0.059 \mathrm{kmol}_{\mathrm{c}} \mathrm{ha}^{-1} \mathrm{a}^{-1}$, which corresponds to the same range of rates determined with TDS* (Table 3). Similarly to TDN, inorganic $\mathrm{N}$ fluxes in throughfall also significantly decreased in Othmarsingen, Lausanne, Schänis and Celerina but not in Jussy. The rates varied 


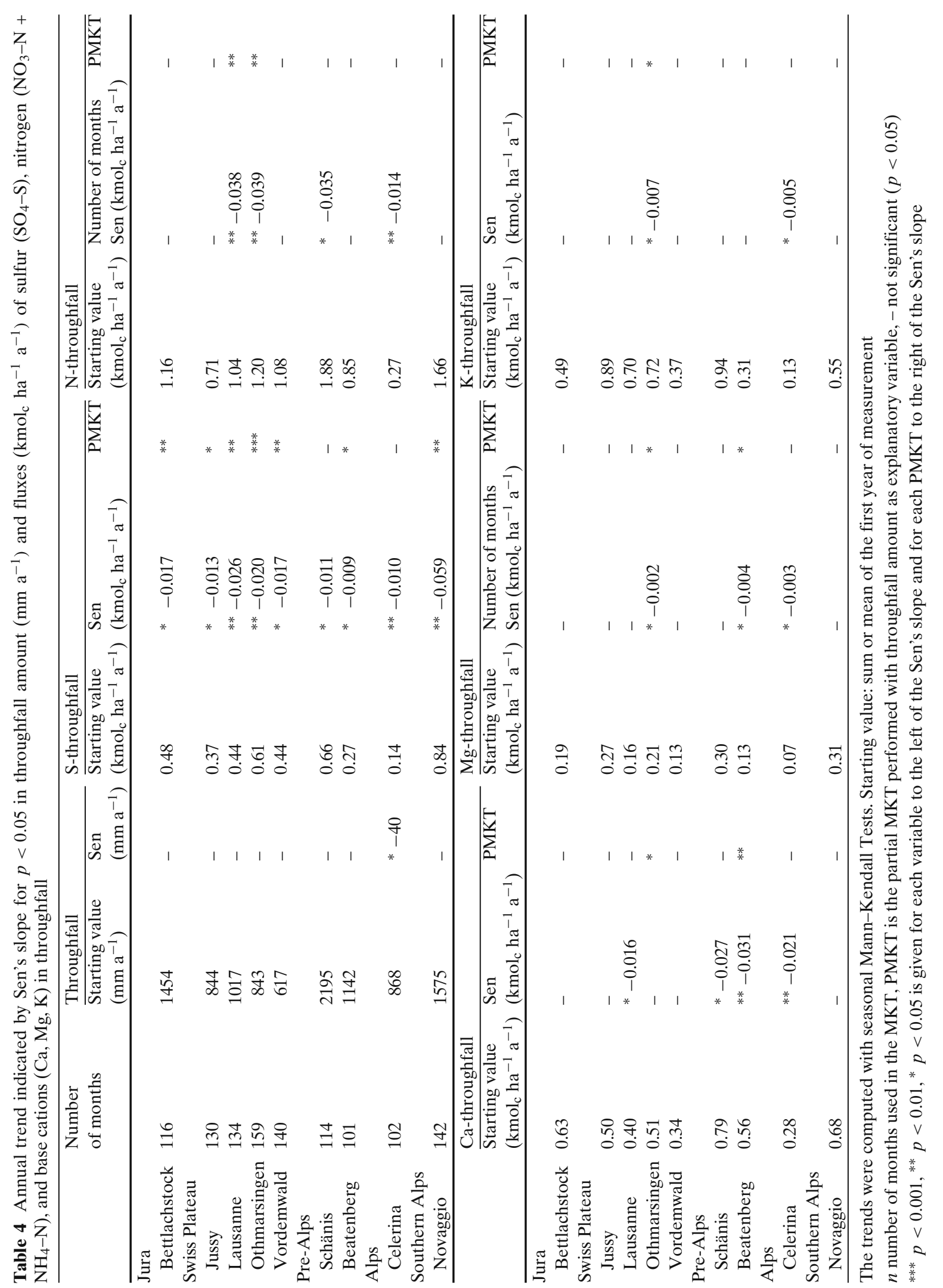


between -0.014 and $-0.039 \mathrm{kmol}_{\mathrm{c}} \mathrm{N} \mathrm{ha}^{-1} \mathrm{a}^{-1}$. The partial Mann-Kendall indicated that variations in precipitation amount were not responsible $(p<0.05)$ for the trends in $\mathrm{S}$ and $\mathrm{N}$ fluxes in throughfall, except in Schänis and Celerina.

Trends in soil solution chemistry

Element concentrations (e.g. $\mathrm{NO}_{3}^{-} \mathrm{N}, \mathrm{BC}$ or $\mathrm{SO}_{4}-$ $\mathrm{S})$ and $\mathrm{BC} / \mathrm{Al}$ ratios strongly decreased at some plots (e.g. Beatenberg, Novaggio) during the first year of measurement (Fig. 3 and Table 5). This might have been caused by the soil disturbance during the installation of lysimeters, resulting in higher mineralization rates as it was reported in Moffat et al. (2002). For this reason, trends were calculated with and without the first year of measurement. The comparison of the seasonal Mann-Kendall Tests calculated with and without the first year of measurements (Tables 5 and 6) indicates that several significant trends (e.g. in Novaggio, Beatenberg, Celerina, Schänis) were not significant anymore when the first year of measurements was removed. Based on these results, we only considered the trends calculated without the first year of measurements.

The seasonal Mann-Kendall tests computed with monthly values of $\mathrm{BC} / \mathrm{Al}$ ratios indicated that no significant trend in $\mathrm{BC} / \mathrm{Al}$ ratios could be found in Lausanne, Celerina and Novaggio at any soil depths (Table 5). Figure 3 also shows that despite the large seasonal variations at these sites, $\mathrm{BC} / \mathrm{Al}$ remained stable on average at a depth of 15 and $80 \mathrm{~cm}$. Significant decreases in $\mathrm{BC} / \mathrm{Al}$ were found at two sites only, in Beatenberg at a depth of $15 \mathrm{~cm}$ and in Vordemwald at a depth of 15 and $50 \mathrm{~cm}$ (Table 5). The decrease in BC/Al in Beatenberg was due to a decline in base cation concentrations, while in Vordemwald, BC decreased stronger than $\mathrm{Al}$ (Table 5). The rate of decrease was slow in Vordemwald ( $\left.-0.05 \mathrm{BC} / \mathrm{Al} \mathrm{a}^{-1}\right)$ and represented an annual decrease of $1 \%$ to $4 \%$. In Beatenberg, the decrease was proportionally faster $(-7 \%$ yearly) at a depth of $15 \mathrm{~cm}$.
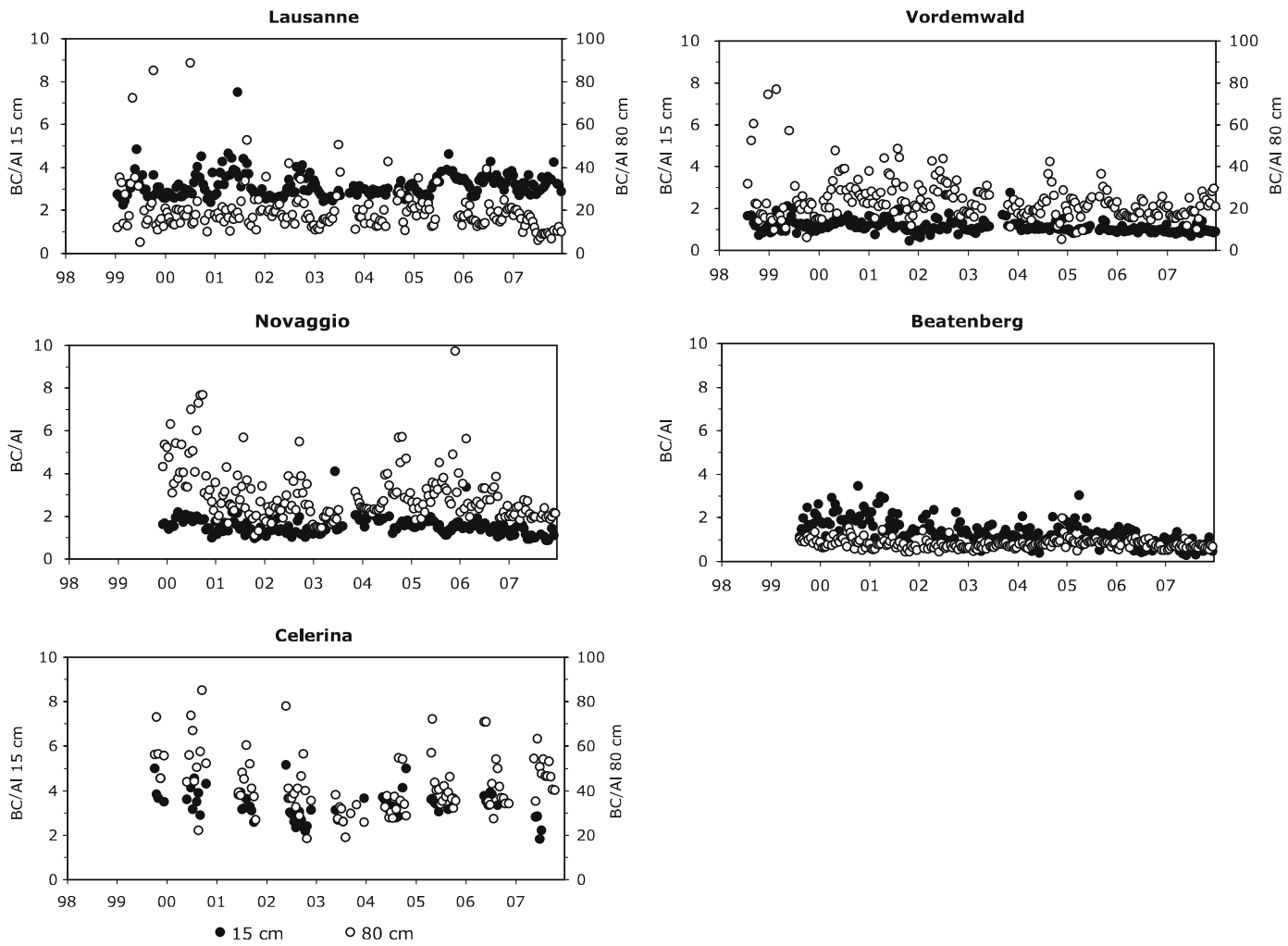

Fig. 3 Molar BC/Al ratio in the soil solution at a depth of 15 and $80 \mathrm{~cm}$ at the five sites with acid soil solution $(\mathrm{pH}<5.5)$ 


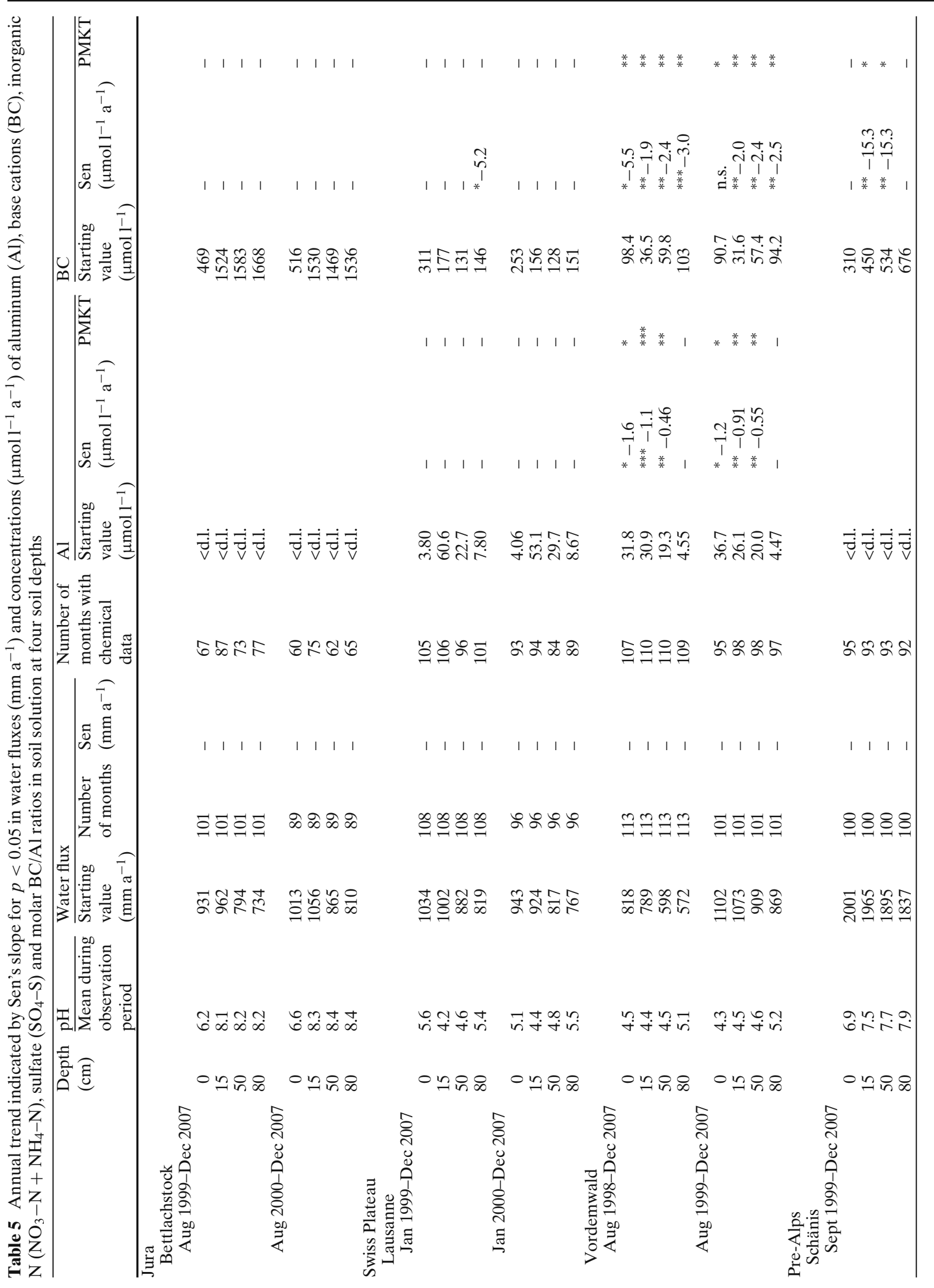




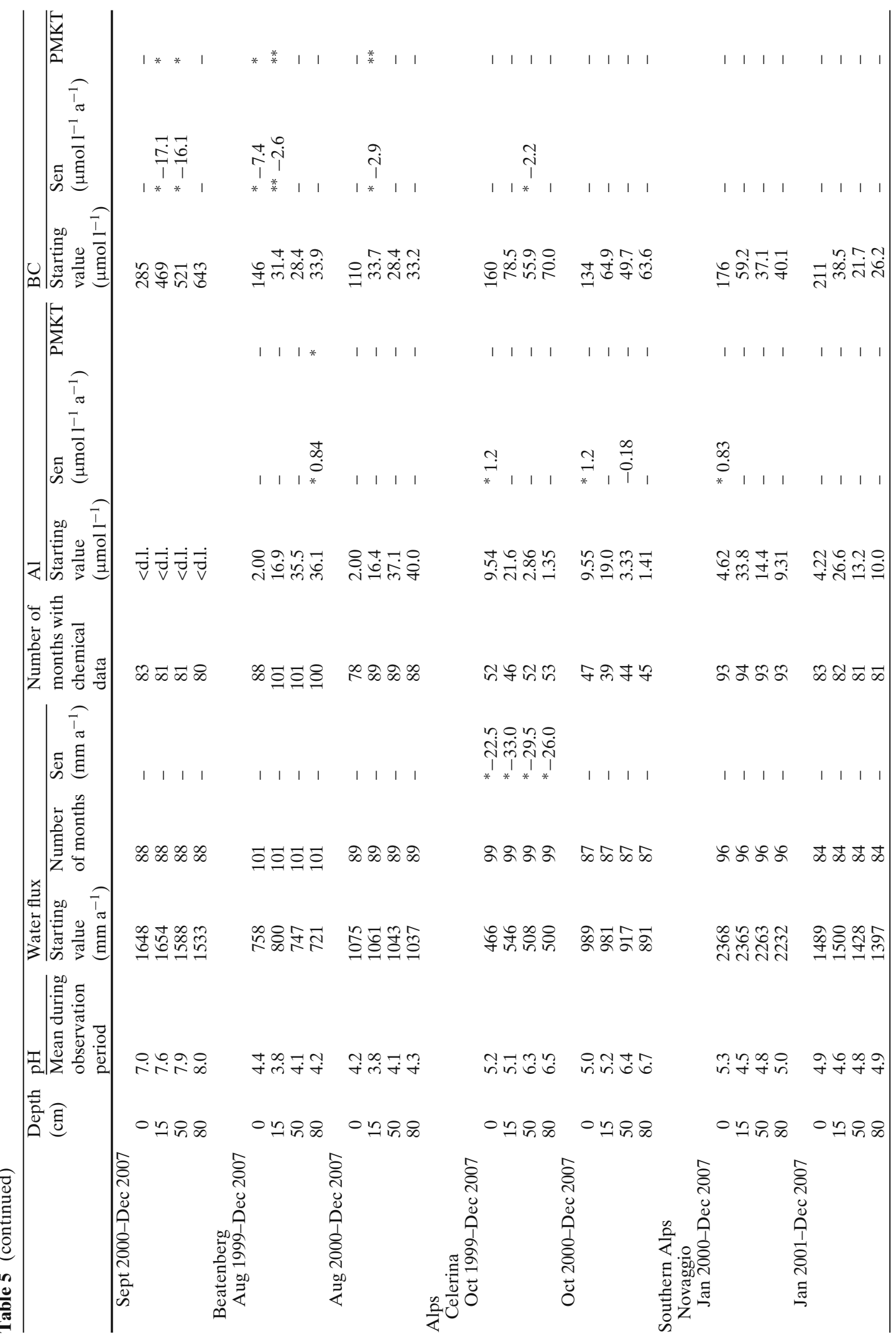




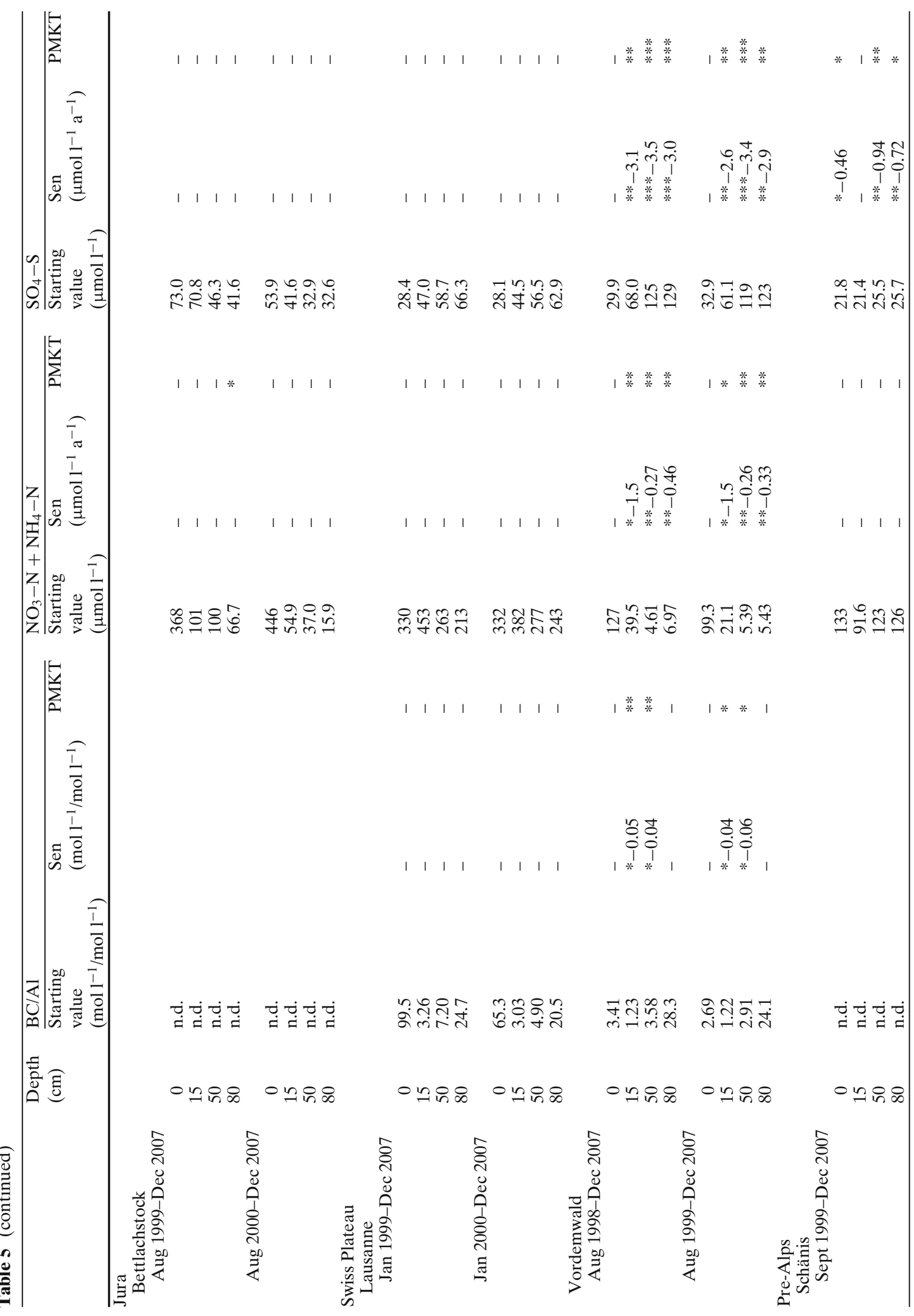




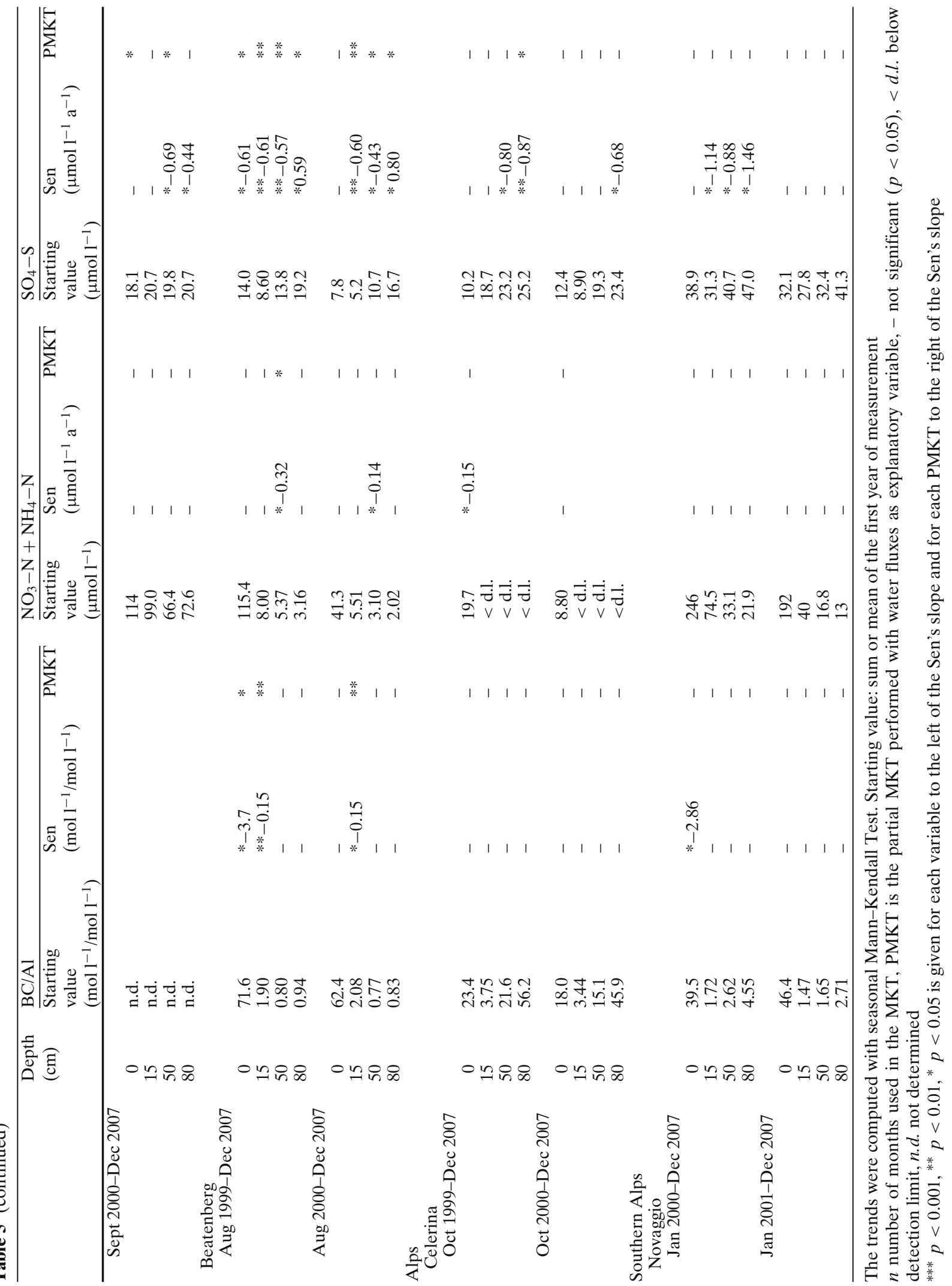




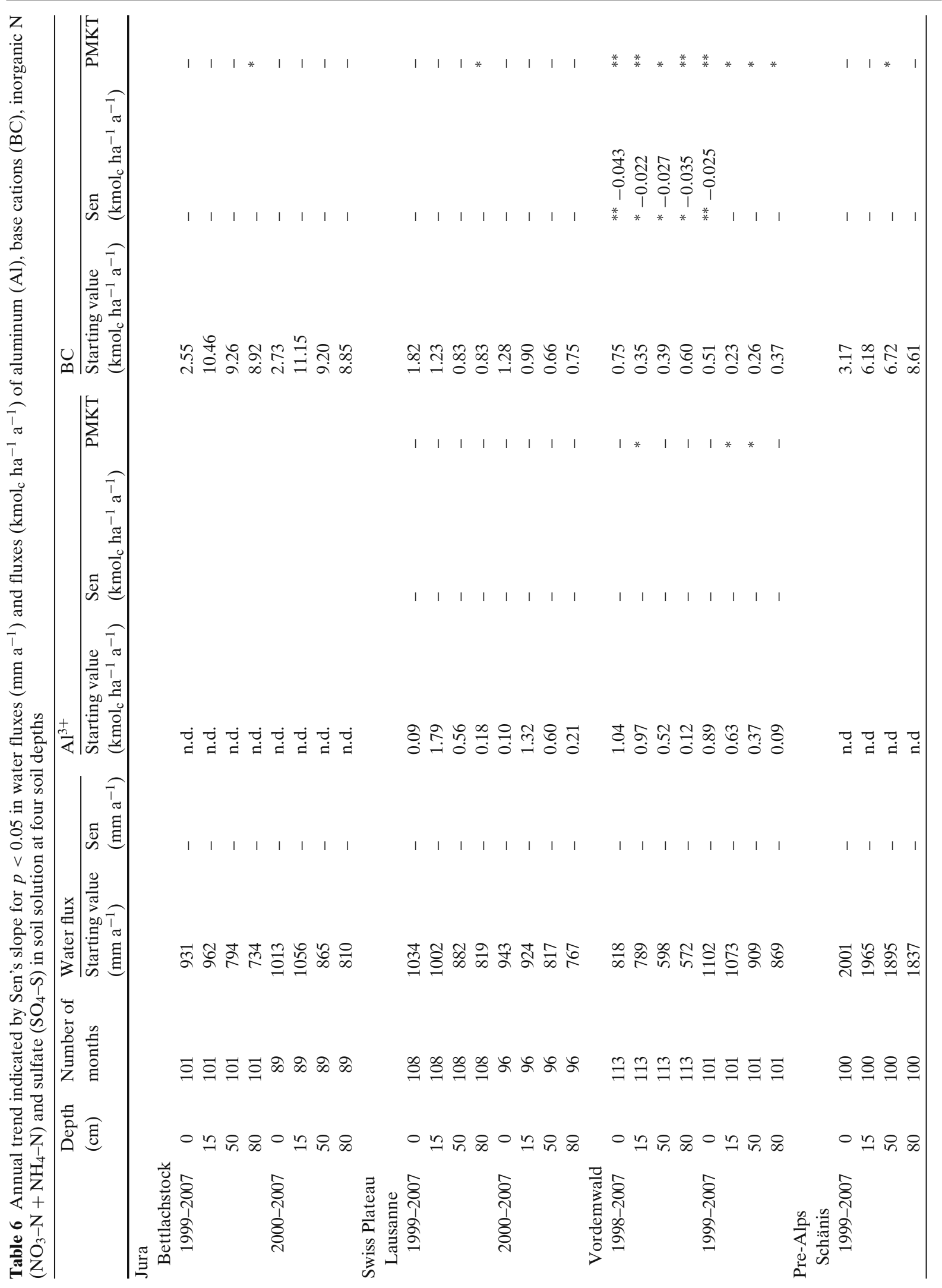




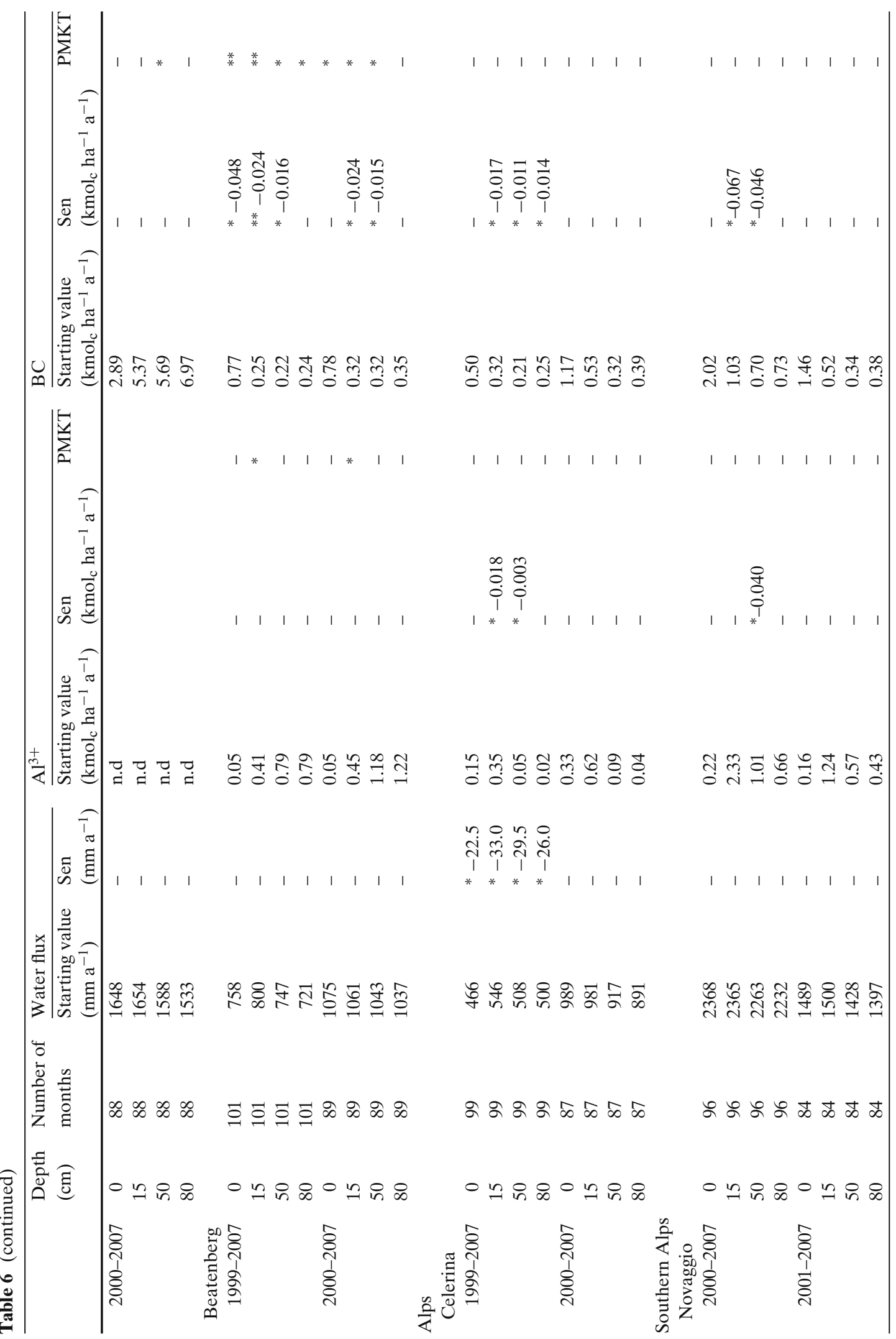




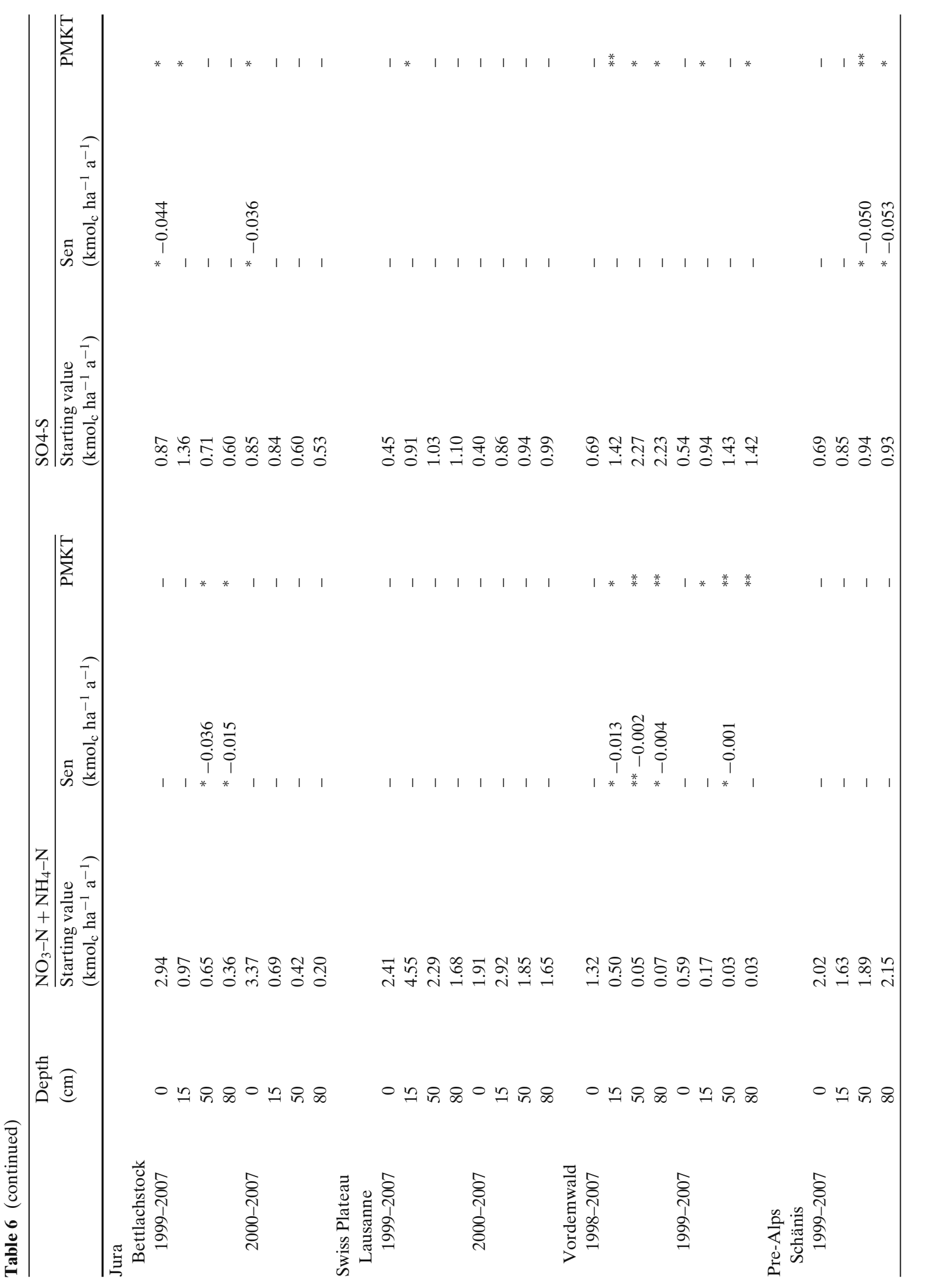




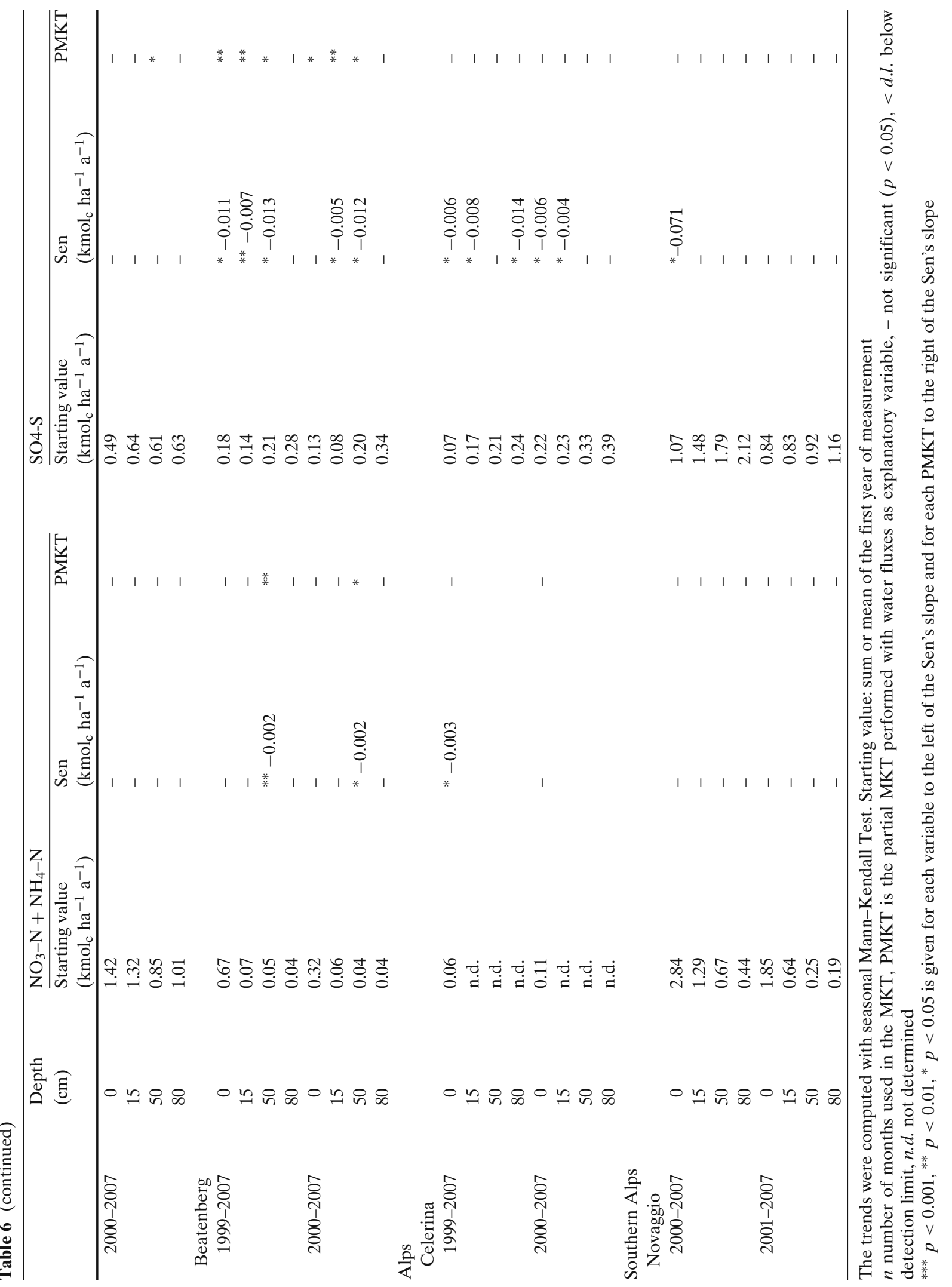


Significant decreasing trends in $\mathrm{SO}_{4}-\mathrm{S}$ concentrations were found at four sites (Beatenberg, Celerina, Schänis, and Vordemwald) at different soil depths. The trend found in Celerina was not significant anymore when the water flux was included as explanatory variable in the PMKT, suggesting that the decline was mainly caused by a dilution effect. Inorganic $\mathrm{N}\left(\mathrm{NO}_{3}-\mathrm{N}+\mathrm{NH}_{4}-\mathrm{N}\right)$ declined mostly in Vordemwald in the mineral horizons $(15,50$, and $80 \mathrm{~cm})$ and also in Beatenberg, but only at a depth of $50 \mathrm{~cm}$. Element concentrations at the different soil depths remained stable in Lausanne and in Bettlachstock (Table 5).

Similarly to the trends in $\mathrm{SO}_{4}-\mathrm{S}$ concentrations, $\mathrm{SO}_{4}-\mathrm{S}$ fluxes significantly decreased in Beatenberg, Celerina, Schänis, Vordemwald, and Bettlachstock at different soil depths (Table 6). In Celerina, the PMKT indicated that the trends at the different soil depths were not significant anymore when the water fluxes were included in the test, suggesting that the variations of $\mathrm{SO}_{4}-\mathrm{S}$ fluxes were mainly caused by changes in water fluxes. $\mathrm{SO}_{4}-\mathrm{S}$ fluxes leaving the root zone $(80 \mathrm{~cm})$ did not show any significant trend at any site except in Vordemwald where $\mathrm{SO}_{4}-\mathrm{S}$ decreased in the PMKT. Significant decreases in inorganic $\mathrm{N}$ fluxes were found in Vordemwald and in Beatenberg but the fluxes were very low $\left(<1 \mathrm{~kg} \mathrm{ha}^{-1} \mathrm{a}^{-1}\right)$ due to the low $\mathrm{N}$ concentrations. BC fluxes decreased significantly in Beatenberg and in Vordemwald.

Mean $\mathrm{SO}_{4}-\mathrm{S}$ fluxes increased with soil depth at the seven sites (Table 6). Output $\mathrm{SO}_{4}-\mathrm{S}$ fluxes from the root zone $(80 \mathrm{~cm})$ exceeded throughfall input in Lausanne, Vordemwald and Novaggio or were similar in Schänis, Bettlachstock, Beatenberg, and Celerina. There was no significant trend in the difference between input and output (data not shown).

The output of inorganic $\mathrm{N}$ varied greatly from site to site. In Vordemwald, Beatenberg and Celerina, the output fluxes were negligible $\left(<1 \mathrm{~kg} \mathrm{ha}^{-1} \mathrm{a}^{-1}\right)$, small $\left(2-6 \mathrm{~kg} \mathrm{ha}^{-1} \mathrm{a}^{-1}\right)$ in Novaggio and Bettlachstock, and large $(>10$ $\mathrm{kg} \mathrm{ha} \mathrm{h}^{-1} \mathrm{a}^{-1}$ ) in Schänis and Lausanne (Fig. 4).
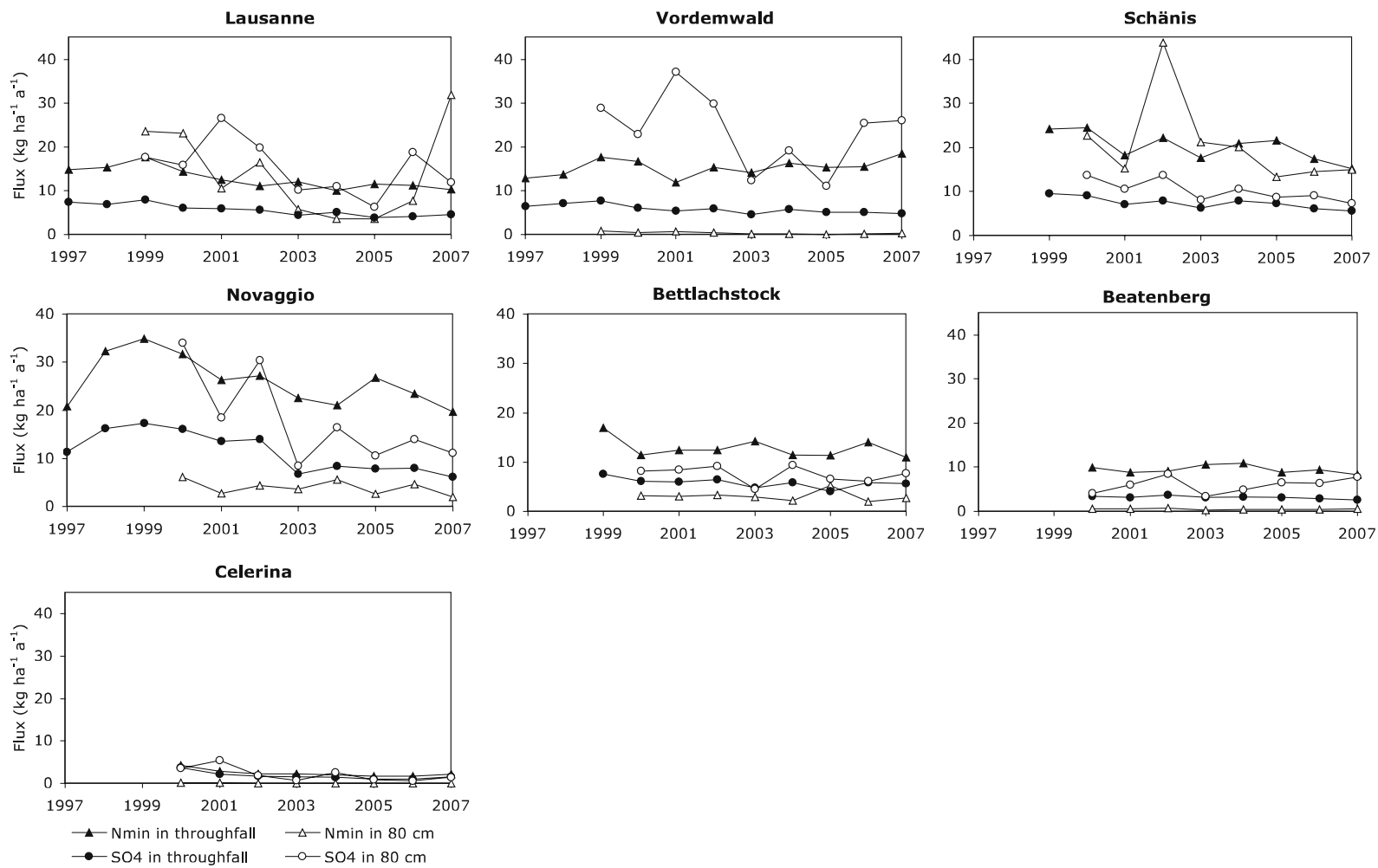

Fig. 4 Annual inorganic $\mathrm{N}$ and $\mathrm{SO}_{4}-\mathrm{S}$ fluxes $\left(\mathrm{kg} \mathrm{ha}^{-1} \mathrm{a}^{-1}\right)$ in throughfall and in soil solution at a depth of $80 \mathrm{~cm}$ 
The output fluxes were generally much lower than the input throughfall fluxes except in Lausanne and Schänis (Fig. 4). At these two sites, the difference between input and output varied considerably with time. The $\mathrm{N}$ release from the soil was in some years much larger than the input (e.g., 2007 in Lausanne, 2002 in Schänis), while in other years, it was much smaller (e.g., 2003-2005 in Lausanne). The large annual $\mathrm{N}$ flux in 2007 in Lausanne was due to high concentrations of $\mathrm{NO}_{3}-\mathrm{N}$ in July and August combined with large water fluxes. Similarly in Schänis, large $\mathrm{NO}_{3}-\mathrm{N}$ concentrations coupled to large water fluxes in the fall 2002 resulted in large annual $\mathrm{N}$ output. In Celerina, both input and output fluxes were low $\left(\leq 4 \mathrm{~kg} \mathrm{ha}^{-1} \mathrm{a}^{-1}\right)$.

\section{Discussion}

\section{Atmospheric acid deposition}

The relatively high deposition loads of acidity (TDA) at Novaggio and Schänis are typical for areas at the foothills of mountain ranges in the proximity of industrialized or agricultural areas such as the Italian Po Plain and the Swiss Plateau (Waldner et al. 2007). These exposed areas are subjected to air pollutants as the plain regions but receive higher precipitation, resulting in higher acid deposition rates. In contrast, the load of acidity was low in Celerina, since it is located in an intra-alpine plain, remote from pollutant sources. The regional distribution of atmospheric $\mathrm{S}$ and $\mathrm{N}$ deposition at the study sites was already discussed in Thimonier et al. (2005) and Waldner et al. (2007). The highest loads found at the study sites (Novaggio and Schänis) were at the beginning of the observation period in the same range (Table 3 ) as those found in 1997 in the western and central part of Europe at the monitoring sites of ICPForests (Table 4 in De Vries et al. 2003). The atmospheric inputs of acidity estimated at the Swiss sites $\left(0-2 \mathrm{kmol}_{\mathrm{c}} \mathrm{ha}^{-1} \mathrm{a}^{-1}\right)$ were in the lower range of those $\left(0.2-4 \mathrm{kmol}_{\mathrm{c}} \mathrm{ha}^{-1} \mathrm{a}^{-1}\right)$ determined by De Vries et al. (2003).

A significant decrease in acid deposition (TDA) was found at only three out of nine study sites (Othmarsingen, Lausanne and Jussy). The decline (about $-0.7 \mathrm{kmol}_{\mathrm{c}} \mathrm{ha}^{-1}$ from 1998 to 2007) mainly resulted from a significant decrease in total $\mathrm{N}$ deposition (about $-0.55 \mathrm{kmol}_{\mathrm{c}} \mathrm{ha}^{-1}$ or $-7.7 \mathrm{~kg} \mathrm{~N} \mathrm{ha}^{-1}$ from 1998 to 2007). A strong decrease in acid deposition was also found in Novaggio, but it was likely related to the variations in precipitation amount. At the five other sites, no decline in TDA could be found although total S deposition (TDS*) significantly decreased. Since there was no trend in TDBC at most plots and TDN was larger than TDS*, trends in acid deposition depended mainly on the development of $\mathrm{N}$ deposition. De Vries et al. (2003) also emphasized that $\mathrm{N}$ deposition in 1997 was higher than $\mathrm{S}$ deposition at a European wide scale. The $\mathrm{S}$ emissions and thereby $\mathrm{S}$ deposition had continuously declined over large parts of Europe since the mid-1990s, whereas $\mathrm{NH}_{3}$ emissions mostly stayed constant or even increased. In Switzerland also, while $\mathrm{S}$ emission has continued to decrease after 1995, emission of nitrogen oxides and ammonia diminished in a less extent (FOEN 2009). This corresponds to the trends determined in our study. In a ten-year period (1998-2007), TDS* decreased by $0.53 \mathrm{kmol}_{\mathrm{c}} \mathrm{ha}^{-1}\left(7.4 \mathrm{~kg} \mathrm{ha}^{-1}\right)$ in Novaggio in Southern Switzerland, between 0.14 and $0.25 \mathrm{kmol}_{\mathrm{c}} \mathrm{ha}^{-1}\left(2.0-3.5 \mathrm{~kg} \mathrm{ha}^{-1}\right)$ on the Swiss Plateau, and $0.1 \mathrm{kmol}_{\mathrm{c}} \mathrm{ha}^{-1}\left(1.4 \mathrm{~kg} \mathrm{ha}^{-1}\right)$ at sites located in mountainous areas, remote from pollution sources (Beatenberg and Celerina). The different development of $\mathrm{S}$ and $\mathrm{N}$ deposition was also reported at two stations (Payerne and Dübendorf) of the Swiss National Air Pollution Monitoring Network (NABEL) where wet deposition has been measured since 1985 (FOEN 2009). The $\mathrm{SO}_{4}-\mathrm{S}$ load at the NABEL stations decreased from 8 to $2 \mathrm{~kg} \mathrm{~S} \mathrm{ha}^{-1} \mathrm{a}^{-1}$ with a strong decline between 1985 and 1997 and a slower one until 2008. In contrast to the decreasing trends in $\mathrm{S}$ deposition, wet deposition of $\mathrm{NO}_{3}^{-} \mathrm{N}, \mathrm{NH}_{4}-$ $\mathrm{N}$, and base cations remained stable (FOEN 2009). Similarly, wet deposition of nitrogen at the Lägern near Zürich on the Swiss Plateau was about $9 \mathrm{~kg} \mathrm{ha}^{-1} \mathrm{a}^{-1}$ in the late 1980s (Klöti et al. 1989) and decreased only to $7 \mathrm{~kg} \mathrm{ha}^{-1} \mathrm{a}^{-1}$ in 2001 (Burkard et al. 2003). Measurements of wet deposition at 17 monitoring sites across the Alps in Italy, Austria, France, and Switzerland also showed a significant reduction of sulfate 
concentrations at all sites, a slight decrease in nitrate, statistically significant only at a few sites, and a more widespread decline of ammonium (Rogora et al. 2006). In northern and central Europe, De Vries et al. (2003) also showed the larger decrease in $\mathrm{S}$ deposition compare to $\mathrm{N}$ at 53 plots from a comparison of annual N/S ratios in bulk deposition and throughfall in the early 1980s (Ivens 1990) and in the 1990s (Erisman and De Vries 1999). This illustrates the rather constant load of nitrogen for the last 20 years compared to the substantial decrease in $\mathrm{SO}_{4}-\mathrm{S}$, which caused $\mathrm{N}$ to be a dominating factor in the acidic input in large parts of Europe.

Because of the large numbers of tests in Tables 3 and 4 (about 100 tests), it is likely that five tests show a significance at $p<0.05$ just by chance (type I error). However, the majority of the trends presented in both tables have lower $p$ values (e.g. $p<0.01$ or $p<0.001$ ), which indicates that the trends are effective and not due to chance. Furthermore, significance levels of the negative trends found for S, N, and acid deposition seem to be related to the start of the measurement period. The earlier the time series started, the higher is the significance level. This is in line with the fact that the reduction of $\mathrm{N}$ and $\mathrm{S}$ emissions mainly occurred in the decade 1990 to 2000.

Trends in deposition might be caused by variations in precipitation amount and not by changes in emissions. Thimonier et al. (2005) showed that annual $\mathrm{N}$ and $\mathrm{SO}_{4}-\mathrm{S}$ deposition at the study sites positively correlated with the annual precipitation amounts at the regional level (plot-to-plot variation), as well as at the plot level (year-to-year variation for each plot). For this reason, the partial Mann-Kendall test (PMKT) represents a relevant test to detect the influence of precipitation variation on deposition trends (Libiseller and Grimvall 2002). The PMKT indicated that the $\mathrm{N}$ and $\mathrm{SO}_{4}-\mathrm{S}$ deposition trends in Schänis were probably caused by variations in precipitation amount, even though no significant trend $(p<$ 0.05 ) was found in precipitation (Tables 3 and 4). These findings suggest that the observation period should be long enough ( $>10$ years) to detect changes not caused by the precipitation amount, in particular at sites with high precipitation amount and large variability in precipitation.
The reductions in annual total deposition and throughfall chemistry presented in Tables 3 and 4 ranged on average between $-30 \%$ and $-50 \%$ of the values measured during the first year of observation. The changes were larger than the accuracy of $\pm 30 \%$ recommended by the manual on deposition of ICP-Forests (UNECE 2009). However, some significant trends like the decrease in $\mathrm{Mg}$ and $\mathrm{K}$ in throughfall in Othmarsingen were smaller ( $-16 \%$ and $-13 \%$, respectively), showing the high accuracy of the throughfall analysis.

\section{Soil solution}

The most striking finding from the trend analysis of element concentrations and $\mathrm{BC} / \mathrm{Al}$ ratios in the soil solution at the seven sites was the very small number of significant trends determined with the seasonal Mann-Kendall Test. This suggests that the soil solution was relatively little influenced by the recent changes in throughfall deposition or that the trends were too small to be detected. At the sites where the soil has a large capacity to neutralize acid deposition (Bettlachstock and Schänis), it is clear that no substantial changes were expected in the soil solution chemistry. Only the $\mathrm{SO}_{4}-\mathrm{S}$ fluxes below the litter layer responded to the decrease in $\mathrm{SO}_{4}-\mathrm{S}$ throughfall in Bettlachstock (Table 6). At sites located far from pollution sources like in Celerina and in Beatenberg, it can be also expected that the soil solution chemistry did not change much. Indeed $\mathrm{BC} / \mathrm{Al}$, concentrations and fluxes in the soil solution in Celerina remained stable during the observation period (1999-2007), suggesting that acidification was very slow and not detectable within an 8-year period. The trends of element concentrations and fluxes detected by the seasonal Mann-Kendall Tests were mostly due to variations in precipitation amount (Tables 5 and 6). In Beatenberg, the decline in $\mathrm{SO}_{4}-\mathrm{S}$ concentrations and fluxes detected in the soil solution might have been caused by the decrease in $\mathrm{S}$ in throughfall. Similarly, the decrease in $\mathrm{BC}$ in the soil solution might result from the reduction in $\mathrm{BC}$ from throughfall during the observation period (Table 4). Since the $\mathrm{BC}$ concentrations in the soil solution between 15 and $80 \mathrm{~cm}$ of depth were in the same order of magnitude as those measured in throughfall, 
the concentrations in the soil solution might have reacted very fast to variations in throughfall input. On the other hand, the upper soil in Beatenberg is characterized by a thick organic $(\mathrm{Oe}+\mathrm{Oa})$ horizon of $15 \mathrm{~cm}$ where the mineralization of the organic matter likely controls BC concentrations in the soil solution. Variations in meteorological conditions (soil temperature, precipitation) might, therefore, explain the decrease in BC concentrations. Changes in $\mathrm{BC}$ input from the early stage decomposition of the spruce litter seem unlikely. Based on a mean annual BC input of $7 \mathrm{~kg} \mathrm{ha}^{-1} \mathrm{a}^{-1}$ from litterfall (data not shown) and a decay constant $\mathrm{k}$ of $0.437 \mathrm{a}^{-1}$ (Heim and Frey 2004) in Beatenberg, the estimated annual input of $\mathrm{BC}$ from litter decomposition would be quite small ( $3 \mathrm{~kg} \mathrm{BC} \mathrm{ha} \mathrm{k}^{-1} \mathrm{a}^{-1}$ ) compared to the throughfall input (10-17 $\left.\mathrm{kg} \mathrm{BC} \mathrm{ha}^{-1} \mathrm{a}^{-1}\right)$.

Acidification of soil solution was mainly expected in acid soils developed from acid substrate having received substantial atmospheric inputs of acidic compounds for decades like in Novaggio (Blaser et al. 1999). However, the seasonal MannKendall test on $\mathrm{BC} / \mathrm{Al}$ ratios between 2000 and 2007 did not indicate any significant trend in Novaggio, suggesting that acidification was very slow and not detectable within an 8-year period. This is in agreement with the observations at another site (Copera) in southern Switzerland between 1987 and 2003 where a marked decrease in $\mathrm{BC} / \mathrm{Al}$ was reported until the end of the 1990s (Blaser et al. 1999), followed by a stabilization of the ratios (Graf Pannatier et al. 2005). These findings suggest that acidification of soil solution slowed down at the end of the 1990s, probably due to the substantial reduction in $\mathrm{S}$ emissions between 1985 and 1995. Concentrations and fluxes of nitrogen $\left(\mathrm{NH}_{4}-\mathrm{N}+\mathrm{NO}_{3}-\mathrm{N}\right), \mathrm{SO}_{4}-\mathrm{S}$ and base cations (Tables 5 and 6) remained stable in Novaggio, indicating that the system was stable during the observation period. The negative trends in $\mathrm{SO}_{4}-\mathrm{S}$ concentration at different soils depths between 2000 and 2007 (Table 5) was probably not meaningful for the site, since it disappeared when the first year of measurement was removed. In addition, since variations in precipitation and water fluxes influenced concentrations and fluxes in the soil solution as indicated by the partial Mann-Kendall Tests, a longer time series would be necessary to detect changes not related to water fluxes. The increase in $\mathrm{Al}$ concentration observed below the litter layer $(0 \mathrm{~cm})$ probably resulted from the deposition of eroded mineral material or directly from the erosion of the litter layer. The site is located on a steep slope (68\%) in a region characterized by intense precipitation, which sporadically leads to erosion of soil surface.

No trend in soil solution chemistry could be found in Lausanne, although acid deposition (TDA) and input in throughfall ( $\mathrm{N}$ and $\mathrm{SO}_{4}$ S) declined. The lack of reaction was probably due to active internal soil processes (e.g. fast decomposition of litter) that masked the changes in atmospheric deposition at the time scale of the observation period (9 years). In addition, the $\mathrm{BC}$, $\mathrm{Al}$, and $\mathrm{NO}_{3}$ concentrations in the soil solution in Lausanne were characterized by a high variability, exceeding the variations in atmospheric deposition. In contrast to Lausanne, element concentrations and $\mathrm{BC} / \mathrm{Al}$ ratios in Vordemwald significantly decreased, while acid deposition remained constant. While the decrease in base cations, nitrate, and sulfate in the soil solution would indicate a recovery because of the resulting increase in the acid neutralizing capacity (data not shown, Fölster et al. 2003), the preferential loss of base cations compared to $\mathrm{Al}$ suggests that the acidification of soil solution was proceeding quite fast in Vordemwald. This is in agreement with the observations of Boxman et al. (2008) in a Scots pine forest in the Netherlands. Although these authors found a decreasing leaching of nitrate and sulfate at a soil depth of $90 \mathrm{~cm}$ due to the reduction in nitrogen and sulfur deposition, they also reported a continuing acidification marked by a $\mathrm{pH}$ decrease in the upper soil. The reasons for the decline in concentrations and the stronger decrease in base cations compared to $\mathrm{Al}$ in Vordemwald are not completely clear. Aggradation and accumulation of nutrients (e.g. BC, $\mathrm{N}$ ) in the humus layer (Oe horizon) in this vigorous growing stand (mean age of 100 years for Abies alba) might explain the decrease in $\mathrm{BC}$ and $\mathrm{N}$ concentrations, but no observations could confirm this hypothesis. Like in Beatenberg, the fact that $\mathrm{Al}$ concentrations decreased less than $\mathrm{BC}$ was probably due to the high proportion of exchangeable $\mathrm{Al}$ cations in these low base 
saturation soils (Table 2). Speciation of dissolved aluminum into mononuclear inorganic and organic $\mathrm{Al}$ species could give some insight into possible changes in the fractions of $\mathrm{Al}$ species with time. Aluminum was fractionated at the beginning of the monitoring period only. It showed that $\mathrm{Al}$ was partly complexed to dissolved organic matter in Vordemwald and Beatenberg (Graf Pannatier et al. 2004). The modeling of Al species during the whole observation period with a chemical equilibrium model for waters could provide us some indications about possible changes in $\mathrm{Al}$ species with time.

The increasing $\mathrm{SO}_{4}-\mathrm{S}$ fluxes with soil depth in Vordemwald (Table 6) and the large release of $\mathrm{SO}_{4}-\mathrm{S}$ below the root zone $\left(24 \mathrm{~kg} \mathrm{ha}^{-1} \mathrm{a}^{-1}\right.$ on average) compared to the throughfall input (6 $\mathrm{kg} \mathrm{ha}^{-1} \mathrm{a}^{-1}$ on average) indicate an internal source of sulfate, particularly at 50 and $80 \mathrm{~cm}$ of depth. As stated in e.g. Prechtel et al. (2001) and in the review of Sokolova and Alekseeva (2008), the net release of sulfate might be caused by four major processes (1) desorption of sulfate, (2) oxidation of reduced S species, (3) excess mineralization of organically bound $\mathrm{S}$, and (4) weathering of S-containing minerals. A mineralogical study of the soil profile in Vordemwald showed that the soil fraction between $63 \mu \mathrm{m}$ and $2 \mathrm{~mm}$ contained up to $9 \%$ hydroxides (data not shown). Desorption of sulfate from $\mathrm{Al}$ and $\mathrm{Fe}$ hydroxides, stored during earlier periods of higher $\mathrm{S}$ deposition, might have occurred. This process was reported in many studies in Europe and was shown to retard recovery of water acidification in response to the declining sulfate deposition (e.g. Alewell et al. 2000a). Reduction and oxidation of stored sulfur in the temporarily waterlogged soil in Vordemwald might have occurred, but no relationship could be found between sulfate fluxes and matric potential data (data not shown).

\section{Input-output budget}

The input-output budget showed that the decrease in $\mathrm{SO}_{4}-\mathrm{S}$ throughfall was not reflected in the output at $80 \mathrm{~cm}$ of depth at most plots (Table 6 and Fig. 4). This lack of response was often reported in studies throughout Europe and was assigned to desorption of previously stored sulfate (e.g., Alewell et al. 2000b; Neirynck et al. 2002; Fölster et al. 2003). It is clear from our data that the soil represented a source of sulfate with $\mathrm{SO}_{4}-$ $\mathrm{S}$ output exceeding input at all plots. Sites located in regions with a long history of $\mathrm{S}$ deposition such as on the Swiss Plateau (Lausanne, Vordemwald) and in Southern Switzerland (Novaggio) showed output much larger than input, suggesting that a large amount of $\mathrm{S}$ was stored in the soil.

The $\mathrm{N}$ budget differed at the seven study sites. Thimonier et al. (2010a) showed that the $\mathrm{C} / \mathrm{N}$ ratio of the soil organic layer, the humus type (e.g. mull, moder) and the pool of organic carbon in the soil played a critical role for nitrate leaching at these sites. The importance of the $\mathrm{N}$ status of the soil is illustrated in Schänis and Novaggio, both sites having received large $\mathrm{N}$ deposition $\left(>25 \mathrm{~kg} \mathrm{ha}^{-1} \mathrm{a}^{-1}\right)$. Little nitrate leaching ( $4 \mathrm{~kg} \mathrm{ha}^{-1} \mathrm{a}^{-1}$ on average between 2000 and 2007) was recorded at Novaggio, characterized by a $\mathrm{C} / \mathrm{N}$ ratio of 24 in the organic layer, a moder humus type, and large organic $\mathrm{C}$ stock. In contrast, the mull-type forest floor in Schänis with a $\mathrm{C} / \mathrm{N}$ ratio of 11 in the upper $5 \mathrm{~cm}$ of the mineral horizon was prone to large nitrate leaching $\left(21 \mathrm{~kg} \mathrm{ha}^{-1} \mathrm{a}^{-1}\right.$ on average between 2000 and 2007). However, the differences between the annual $\mathrm{N}$ output fluxes were substantial between the years in Schänis and Lausanne (Fig. 4). During the period 2003-2005, the annual N, S, and BC output fluxes in Lausanne were lower than the fluxes in the other years because of lower precipitation amount. The concern of increased risk of soil acidification in forest soils after extended periods of summer drought like in summer 2003 (Lamersdorf et al. 1998) was not confirmed by our data. The dry years in Lausanne did not affect the long-term trend of $\mathrm{BC} / \mathrm{Al}$ ratios at a depth of $15 \mathrm{~cm}$ (Fig. 3). In contrast, the large $\mathrm{N}$ output in the wet year 2007, coupled to a large $\mathrm{BC}$ loss, resulted in an increase in acidification as evidenced by the consistent decrease in $\mathrm{BC} / \mathrm{Al}$ ratios at a depth of $80 \mathrm{~cm}$ (Fig. 3).

\section{Conclusions}

The trend analysis of atmospheric deposition (from 1995 or later until 2007) at nine sites and soil solution (from 1999 or 2000 until 2007) at 
seven sites throughout Switzerland showed the following results:

- Reduction of total S deposition (TDS*) was observed at the nine sites; in a 10-year period, the decline in TDS* ranged between 1.4 to $7.4 \mathrm{~kg} \mathrm{ha}^{-1}$, which corresponds to a decrease of $30-50 \%$ at most plots. However, acid deposition (TDA) decreased at three sites only on the Swiss Plateau, mainly due to a decrease in TDN. TDBC* ${ }^{*}$ remained mostly stable. The partial Mann-Kendall Tests indicated that trends in deposition might result from variations in precipitation, especially at sites with high precipitation amount and large variability in precipitation like in Novaggio and in Schänis.

- The soil solution reacted very little to the changes in atmospheric deposition. At five out of the seven study sites, the concentrations and fluxes of $\mathrm{BC}, \mathrm{SO}_{4}-\mathrm{S}$, and inorganic $\mathrm{N}$ remained stable at most soil depths during the observation period. Even in acid soils like in Novaggio that received substantial atmospheric inputs of acidic compounds for decades, the $\mathrm{BC} / \mathrm{Al}$ ratios remained stable, suggesting that acidification was proceeding very slowly (not detectable at this time scale). A stronger reduction in base cations compared to aluminum was detected at two sites, which might indicate that acidification of the soil solution was proceeding faster at these sites.

- The decrease in element concentrations and fluxes in the soil solution in Vordemwald, which could mean a slowing down of acidification since less BC are lost from the soil, was actually coupled to a decrease in $\mathrm{BC} / \mathrm{Al}$, suggesting that acidification was actually proceeding rapidly at the site.

\footnotetext{
Acknowledgements We are grateful to N. Hajjar, O. Schramm, D. Christen, A. Zürcher, A. Brechbühl, Y.Y. Cheung-Tang, and former laboratory staff for sample handling in the field and in the laboratory; the staff from the forest services for collecting the samples on the LWF sites; D. Pezzotta and his team of the WSL central laboratory for analysing the samples, P. Jakob and F. Sutter for the database support, M. Rebetez and G. Schneiter for climatic data. We gratefully acknowledge the financial support of the Federal Office for the Environment (FOEN).
}

\section{References}

Alewell, C., Armbruster, M., Bittersohl, J., Evans, C. D., Meesenburg, H., Moritz, K., et al. (2001). Are there signs of acidification reversal in freshwaters of the low mountain ranges in Germany? Hydrology and Earth System Sciences, 5(3), 367-378.

Alewell, C., Manderscheid, B., Gerstberger, P., \& Matzner, E. (2000a). Effects of reduced atmospheric deposition on soil solution chemistry and elemental contents of spruce needles in NE-Bavaria, Germany. Journal of Plant Nutrition and Soil Science, 163, 509-516.

Alewell, C., Manderscheid, B., Meesenburg, H., \& Bittersohl, J. (2000b). Is acidification still an ecological threat? Nature, 407, 856-857.

Armbruster, M., Abiy, M., \& Feger, K.-H. (2003). The biogeochemistry of two forested catchments in the Black Forest and the eastern Ore Mountains (Germany). Biogeochemistry, 65(3), 341-368.

Belyazid, S., Westling, O., \& Sverdrup, H. (2006). Modelling changes in forest soil chemistry at 16 Swedish coniferous forest sites following deposition reduction. Environmental Pollution, 144, 596-609.

Binkley, D., Driscoll, C. T., Allen, H. L., Schoeneberger, P., \& McAvoy, D. (1989). Acidic deposition and forest soils: Context and case studies of the southeastern United States. New York: Springer. Ecological studies 72 .

Blaser, P., Zysset, M., Zimmermann, S., \& Luster, J. (1999). Soil acidification in Southern Switzerland between 1987 and 1997: A case study based on the critical load concept. Environmental Science and Technology, 33, 2383-2389.

Boxman, A. W., Peters, R. C. J. H., \& Roelofs, J. G. M. (2008). Long term changes in atmospheric $\mathrm{N}$ and $\mathrm{S}$ throughfall deposition and effects on soil solution chemistry in a Scots pine forest in the Netherlands. Environmental Pollution, 156(3), 1252-1259.

Burkard, R., Bützberger, P., \& Eugster, W. (2003). Vertical fogwater flux measurements above an elevated forest canopy at the Lägern research site, Switzerland. Atmospheric Environment, 37, 2979-2990.

Cherubini, P., \& Innes, J. L. (2000). Switzerland: The Swiss long-term forest ecosystem research programme. In J. R. Gosz, C. French, M. Sprott, \& M. White (Eds.), The international long term ecological research network 2000. Perspectives from participating networks (pp. 56-59). Albuquerque: University of New Mexico.

Cronan, C. S., \& Grigal, D. F. J. (1995). Use of calcium/aluminium ratios as indicators of stress in forest ecosystems. Environmental Quality, 24, 209-226.

De Vries, W., Reinds, G. J., van der Salm, C., Draaijers, G. P. J., Bleeker, A., Erisman, J. W., et al. (2001). Intensive monitoring of forest ecosystems in Europe (177 pp.). 2001 Technical Report, EC, UN/ECE, Brussels, Geneva.

De Vries, W., Reinds, G. J., \& Vel, E. (2003). Intensive monitoring of forest ecosystems in Europe 2: Atmospheric deposition and its impacts on soil solution chemistry. Forest Ecology and Management, 174, 97-115. 
Erisman, J. W., \& De Vries, W. (1999). Nitrogen turnover and effects in forests. ECN report RX 99035. Contribution to the Welt Forum 2000 Workshop, July 2-5, Slotau, Germany (34 pp.).

Evans, C. D., Cullen, J. M., Alewell, C., Kopácek, J., Marchetto, A., Moldan, F., et al. (2001). Recovery from acidification in European surface waters. $\mathrm{Hy}$ drology and Earth System Sciences, 5, 283-297.

FAO (1988). FAO/Unesco Soil Map of the World, Revised Legend, with corrections and updates. World Soil Resources Report 60, FAO, Rome. Reprinted with updates as Technical Paper 20, ISRIC, Wageningen 1997.

FOEN (2009). NABEL - La pollution de l'air 2008. Mesures exécutées à l'aide du Réseau national d'observation des polluants atmosphériques (NABEL). Etat de l'environnement $n^{\circ}$ 0919. Berne: Office fédéral de l'environnement.

Fölster, J., Bringmark, L., \& Lundin, L. (2003). Temporal and spatial variations in soil water chemistry at three acid forest sites. Water, Air and Soil Pollution, 146, 171-195.

Graf Pannatier, E., Luster, J., Zimmermann, S., \& Blaser, P. (2005). Acidification of soil solution in a chestnut forest stand in southern Switzerland: Are there signs of recovery? Environmental Science and Technology, 39, 7761-7767.

Graf Pannatier, E., Walthert, L., \& Blaser, P. (2004). Solution chemistry in acid forest soils: Are the BC:Al ratios as critical as expected in Switzerland. Journal of Plant Nutrition and Soil Science, 167, 160-168.

Gundersen, P., Schmidt, I. K., \& Raulund-Rasmussen, K. (2006). Leaching of nitrate from temperate forests Effects of air pollution and forest management. Environmental Reviews, 14(1), 1-57.

Heim, A., \& Frey, B. (2004). Earl stage litter decomposition rates for Swiss forests. Biogeochemistry, 70, 299313.

Hirsch, R. M., \& Slack, J. R. (1984). A nonparametric trend test for seasonal data with serial dependence. Water Resources Research, 20(6), 727-732.

Ivens, W. P. M. F. (1990). Atmospheric deposition onto forests: An analysis of the deposition variability by means of throughfall measurements. Ph.D. thesis, The Netherlands, University of Utrecht.

Jansson, P. E., \& Karlberg, L. (2004). Coupled heat and mass transfer model for soil-plant-atmosphere systems (435 pp.). Stockholm: Royal Institute of Technology, Dept of Civil and Environmental Engineering. http://www.lwr.kth.se/CoupModel/CoupModel.pdf.

KA5 (2005). Bodenkundliche Kartieranleitung. 5. verbesserte und erweiterte Auflage Bundesanstalt für Geowissenschaften und Rohstoffe in Zusammenarbeit mit den Staatlichen Geologischen Diensten der Bundesrepublik Deutschland.

Klöti, P., Keller, H., \& Guecheva, M. (1989). Effects of forest canopy on throughfall precipitation chemistry. In Baltimore symposium (Vol. 179, pp. 203-209). Baltimore: International Association of Hydrological Sciences Publication.

Kvaalen, H., Solberg, S., Clarke, N., Torp, T., \& Aamlid, D. (2002). Time series study of concentrations of $\mathrm{SO}_{4}^{2-}$ and $\mathrm{H}^{+}$in precipitation and soil waters in Norway. Environmental Pollution, 117, 215-224.

Lamersdorf, N. P., Beier, C., Blanck, K., Bredemeier, M., Cummins, T., Farrell, E. P., et al. (1998). Effect of drought experiments using roof installations on acidification/nitrification of soils. Forest Ecology and Management, 101(1-3), 95-109.

Libiseller, C. (2004). MULTMK/PARTMK, a program for the computation of Multivariate and Partial Mann-Kendall Test. Available online at http://www.ekon.slu.se/PMK. Accessed 25 August 2009.

Libiseller, C., \& Grimvall, A. (2002). Performance of partial Mann-Kendall tests for trend detection in the presence of covariates. Environmetrics, 13(1), 71-84.

Likens, G. E., Driscoll, C. T., Buso, D. C., Siccama, T. G., Johnson, C. E., Lovett, G. M., et al. (1998). The biogeochemistry of calcium at Hubbard Brook. Biogeochemistry, 41, 89-173.

Meesenburg, H., Meiwes, K. J., \& Rademacher, P. (1995). Long term trends in atmospheric deposition and seepage output in northwest German forest ecosystems. Water, Air and Soil Pollution, 85, 611-616.

Michalzik, B., Kalbitz, K., Park, J. H., Solinger, S., \& Matzner, E. (2001). Fluxes and concentrations of dissolved organic carbon and nitrogen - A synthesis for temperate forests. Biogeochemistry, 52, 173-205.

Moffat, A. J., Kvaalen, H., Solberg, S., \& Clarke, N. (2002). Temporal trends in throughfall and soil water chemistry at three Norwegian forests, 1986-1997. Forest Ecology and Management, 168, 15-28.

Neirynck, J., Janssens, I. A., Roskams, P., Quataert, P., Verschelde, P., Ceulemans, R. (2008). Nitrogen biogeochemistry of a mature Scots pine forest subjected to high nitrogen loads. Biogeochemistry, 91, 201-222.

Neirynck, J., Van Ranst, E., Roskams, P., \& Lust, N. (2002). Impact of decreasing throughfall depositions on soil solution chemistry at coniferous monitoring sites in northern Belgium. Forest Ecology and Management, 160, 127-142.

Oulehle, F., Hofmeister, J., Cudlin, P., \& Hruska, J. (2006). The effect of reduced atmospheric deposition on soil and soil solution chemistry at a site subjected to longterm acidification, Nacetin, Czech Republic. Science of the Total Environment, 370(2-3), 532-544.

Prechtel, A., Alewell, C., Armbruster, M., Bittersohl, J., Cullen, J. M., Evans, C. D., et al. (2001). Response of sulphur dynamics in European catchments to decreasing sulphate deposition. Hydrology and Earth System Sciences, 5, 311-325.

Reinds, G. J., Posch, M., \& De Vries, W. (2009a). Modelling the long-term soil response to atmospheric deposition at intensively monitored forest plots in Europe. Environmental Pollution, 157(4), 1258-1269.

Reinds, G. J., Posch, M., \& Leemans, R. (2009b). Modelling recovery from soil acidification in European forests under climate change. Science of the Total Environment, 407(21), 5663-5673.

Reuss, J. O., \& Johnson, D. W. (1986). Acid deposition and the acidification of soils and waters. New York: Springer. Ecological studies 59. 
Rogora, M., Mosello, R., Arisci, S., Brizzio, M. C., Barbieri, A., Balestrini, A., et al. (2006). An overview of atmospheric deposition chemistry over the Alps: Present status and long-term trends. Hydrobiologia, 562, 17-40.

Schöpp, W., Posch, M., Mylona, S., \& Johansson, M. (2003). Long-term development of acid deposition (1880-2030) in sensitive freshwater regions in Europe. Hydrology and Earth System Sciences, 7(4), 436-446.

Schramm, D., Schultze, B., \& Scherzer, J. (2006). Validierung von Pedotransferfunktionen zur Berechnung von bodenhydrologischen Parametern als Grundlage für die Ermittlung von Kennwerten des Wasserhaushaltes im Rahmen der BZE II. Technical report, TU Bergakademie Freiberg, Freiberg, Germany.

Sen, P. K. (1968). Estimates of the regression coefficient based on Kendall's tau. Journal of American Statistical Association, 63, 1379-1389.

Sokolova, T. A., \& Alekseeva, S. A. (2008). Adsorption of sulfate ions by soils (A Review). Eurasian Soil Science, 41(2), 140-148.

Staelens, J., Houle, D., De Schrijver, A., Neirynck, J., \& Verheyen, K. (2008). Calculating dry deposition and canopy exchange with the canopy budget model: Review of assumptions and application to two deciduous forests. Water, Air and Soil Pollution, 191(1-4), 149169.

Stoddard, J. L., Jeffries, D. S., Lükeville, A., Clair, T. A., Dillon, P. J., Driscoll, C. T., et al. (1999). Regional trends in aquatic recovery from acidification in North America and Europe. Nature, 401, 575-578.

Thimonier, A., Graf Pannatier, E., Schmitt, M., Waldner, P., Walthert, L., Schleppi, P., et al. (2010a). Does exceeding the critical loads for nitrogen alter nitrate leaching, the nutrient status of trees and their crown condition at Swiss Long-term Forest Ecosystem Research (LWF) sites? European Journal of Forest Research, 129, 443-461.

Thimonier, A., Schmitt, M., Cherubini, P., \& Kräuchi, N. (2001). Monitoring the Swiss forest: Building a research platform. In T. Anfodillo \& V. Carraro (Eds.), Monitoraggio ambientale: Metodologie ed applicazioni. Atti del XXXVIII Corso di Cultura in Ecologia (pp. 121-134). Vito di Cadore, Centro Studi per l'Ambiente Alpino, Università degli Studi di Padova.

Thimonier, A., Schmitt, M., Waldner, P., \& Rihm, B. (2005). Atmospheric deposition on Swiss long-term forest ecosystem research (LWF) plots. Environmental Monitoring and Assessment, 104, 81-118.

Thimonier, A., Sedivy, I., \& Schleppi, P. (2010b). Estimating leaf area index in different types of mature forest stands in Switzerland: A comparison of methods. European Journal of Forest Research, 129, 543-562.

Ulrich, B. (1983). Interaction of forest canopies with atmospheric constituents: SO2, alkali and earth alkali cations and chloride. In B. Ulrich \& J. Pankrath (Eds.), Effects of accumulation of air pollutants in forest ecosystems (pp. 33-45). Dordrecht: Reidel.

UNECE (2004). Mapping manual 2004: Manual on methodologies and criteria for modelling and mapping critical loads \& levels and air pollution effects, risks and trends. UNECE Convention on Long-range Transboundary Air Pollution.

UNECE (2008). The Condition of Forests in Europe, 2008 executive report. United Nations Economic Commission for Europe, Convention on Long-range Transboundary Air Pollution, International Co-operative Programme on Assessment and Monitoring of Air Pollution Effects on Forests (ICP Forests).

UNECE (2009). Proposed update of the manual on methods and criteria for harmonized sampling, assessment, monitoring and analysis of the effects of air pollution on forests, Part VI, Sampling and analysis of deposition. In E. Ulrich, R. Mosello, J. Derome, K. Derome, N. Clarke, N. König, et al. (Eds.), Expert panel on deposition. Economic Commission for Europe, Convention on Long-range Transboundary Air Pollution, International Co-operative Programme on Assessment and Monitoring of Air Pollution Effects on Forests (ICP Forests).

Vanguelova, E. I., Benham, S., Pitman, R., Moffat, A. J., Broadmeasdow, M., Nisbet, T., et al. (2010). Chemical fluxes in time through forest ecosystems in the UK Soil response to pollution recovery. Environmental Pollution, 158, 1857-1869.

Waldner, P., Schaub, M., Graf Pannatier, E., Schmitt, M., Thimonier, A., \& Walthert, L. (2007). Atmospheric deposition and ozone levels in Swiss Forests: Are critical values exceeded? Environmental Monitoring and Assessment, 128, 5-17.

Wallman, P., Svennson, M. G. E., Sverdrup, H., \& Belyazid, S. (2005). ForSAFE - An integrated processoriented forest model for long-term sustainability assessments. Forest Ecology and Management, 207, 19-36.

Walthert, L., Blaser, P., Lüscher, P., Luster, J., \& Zimmermann, S. (2003). Langfristige WaldökosystemForschung LWF. Kernprojekt Bodenmatrix. Ergebnisse der ersten Erhebung 1994-199. Zürich, Eidg., Techn. Hochschule. Available online at http://e-collection. ethbib.ethz.ch/cgi-bin/show.pl?type=bericht $\& n r=276$.

Watmough, S. A., \& Dillon, P. D. (2004). Major element fluxes from a coniferous catchment in central Ontario, 1983-1999. Biogeochemistry, 67, 369-398. 